\title{
Brain-derived neurotrophic factor: role in depression and suicide
}

This article was published in the following Dove Press journal:

Neuropsychiatric Disease and Treatment

17 August 2009

Number of times this article has been viewed

\section{Yogesh Dwivedi}

Psychiatric Institute, Department of Psychiatry, College of Medicine, University of Illinois at Chicago,

Chicago, Illinois, USA
Correspondence: Yogesh Dwivedi, PhD Associate Professor, The Psychiatric Institute, Department of Psychiatry, University of Illinois at Chicago, Chicago, IL 606 I2, USA

$\mathrm{Tel}+\mathrm{I}(3 \mid 2) 4 \mid 3-4557$

Fax +I (3I2) 355-3857

Email ydwivedi@psych.uic.edu
Abstract: Depression and suicidal behavior have recently been shown to be associated with disturbances in structural and synaptic plasticity. Brain-derived neurotrophic factor (BDNF), one of the major neurotrophic factors, plays an important role in the maintenance and survival of neurons and in synaptic plasticity. Several lines of evidence suggest that BDNF is involved in depression, such that the expression of BDNF is decreased in depressed patients. In addition, antidepressants up-regulate the expression of BDNF. This has led to the proposal of the "neurotrophin hypothesis of depression". Increasing evidence demonstrates that suicidal behavior is also associated with lower expression of BDNF, which may be independent from depression. Recent genetic studies also support a link of BDNF to depression/suicidal behavior. Not only BDNF, but abnormalities in its cognate receptor tropomycin receptor kinase B (TrkB) and its splice variant (TrkB.T1) have also been reported in depressed/suicidal patients. It has been suggested that epigenetic modulation of the $B d n f$ and $T r k b$ genes may contribute to their altered expression and functioning. More recently, impairment in the functioning of pan75 neurotrophin receptor has been reported in suicide brain specimens. pan 75 neurotrophin receptor is a low-affinity neurotrophin receptor that, when expressed in conjunction with low availability of neurotropins/Trks, induces apoptosis. Overall, these studies suggest the possibility that BDNF and its mediated signaling may participate in the pathophysiology of depression and suicidal behavior. This review focuses on the critical evidence demonstrating the involvement of BDNF in depression and suicide.

Keywords: BDNF, neurotrophins, p75 ${ }^{\mathrm{NTR}}$, Trk receptor, depression, antidepressants, suicide, genetics, epigenetics

\section{Introduction}

Depression and suicide are important public health concerns. Depression affects about $15 \%$ of the population at some point in their lives and is the leading cause of disability worldwide. ${ }^{1}$ About 9 million people are diagnosed as having depression each year in the United States alone, and the lost productivity and treatment expenses burden the US economy by more than US $\$ 43$ billion per year., ${ }^{2,3}$ Depression is associated with an increased number of suicide attempts and increased lethality ${ }^{4,5}$ Suicide accounts for almost $2 \%$ of the world's deaths. ${ }^{6}$ In most of the developed world, suicide is among the top 10 leading causes of death for individuals of all ages, and is the third leading cause of death among adolescents, after motor vehicle accidents and homicide. ${ }^{7-9}$ Several arguments suggest that suicidal behavior is a disorder of its own, although psychiatric disturbances, including depression, are major contributing factors. ${ }^{9}, 10$ Autopsy studies of suicide victims have identified a high rate of major depressive disorder (MDD)

submit your manuscript | www.dovepress.con 
as one of the main causes of increased mortality among suicide victims. ${ }^{11}$ The presence of psychopathology is a strong predictor; however, only a minority of people with such diagnoses commits suicide, which indicates that there is a certain predisposition to suicide that is independent of the main psychiatric disorders..$^{9,12-14}$ Despite the devastating impact of depression and suicide on numerous lives, there is still a dearth of knowledge concerning the mechanisms underlying their pathogenesis.

Overwhelming evidence points to altered synaptic and structural plasticity in patients with depression and in suicidal patients. In fact, it has been proposed that depression/suicide results from an inability of the brain to make appropriate adaptive responses to environmental stimuli as a result of impaired synaptic plasticity and structural plasticity ${ }^{15-18}$ Support for this comes from a variety of studies in major depressed/suicidal subjects demonstrating altered brain structure, such as reduction in cell number, density, cell body size, neuronal and glial density in frontal cortical or hippocampal brain areas and decrease in parahippocampal cortex cortical/laminar thickness. ${ }^{19-27}$ In addition, changes in synaptic circuitry, ${ }^{28}$ decreased dorsolateral prefrontal cortical activity, ${ }^{29,30}$ impaired synaptic connectivity between the frontal lobe and other brain regions, ${ }^{31,32}$ changes in the number and shape of dendritic spines, ${ }^{33,34}$ changes in the primary location of synapse formation, altered dendritic morphology of neurons in the hippocampus, decrease in length and number of apical dendrites, ${ }^{35}$ neuronal atrophy and decreased volume of the hippocampus, ${ }^{36-38}$ decreased number of neurons and glia in cortical areas, ${ }^{39}$ and spatial cognition deficits ${ }^{40}$ have also been reported during stress and depression. Furthermore, depression is associated with negative impact on learning and memory; ${ }^{41-43}$ and stress, a major factor in depression and suicide, hinders performances on hippocampal-dependent memory tasks and impairs induction of hippocampal long-term potentiation. These studies clearly demonstrate impaired structural and functional plasticity in depression and suicide; however, the precise molecular and cellular nature of events that lead to such altered plasticity in these disorders remains unclear.

Survival and development of neurons in the central nervous system (CNS) depends on the influence of a variety of extracellular signals. One set of signals is provided by neurotrophins. The role of neurotrophins in directing brain growth and neuronal functioning is being increasingly recognized. Neurotrophins not only play an important role in cellular proliferation, migration, and phenotypic differentiation and/or maintenance in the developing
$\mathrm{CNS},{ }^{44,45}$ but their presence is required in the adult CNS for maintenance of neuronal functions, structural integrity of neurons, and neurogenesis ${ }^{46,47}$ which suggests that neurotrophins are biologically significant over the entire life span. In addition, a number of studies have demonstrated that neurotrophic factors regulate structural, synaptic, and morphological plasticity to modulate the strength or number of synaptic connections and neurotransmission. ${ }^{48,49}$ Thus, a pathological alteration of the neurotrophic factor system may not only lead to defects in neural maintenance and regeneration and, therefore, structural abnormalities in the brain, but may also reduce neural plasticity and, therefore, impair the individual's ability to adapt to crisis situations.

Mammalian neurotrophins are homodimeric proteins that include nerve growth factor (NGF), brain-derived neurotrophic factor (BDNF), neurotrophin (NT) 3, and NT 4/5. Most functions of neurotrophins are mediated by the tropomycin receptor kinase (Trk) family of tyrosine kinase receptors. The interaction of neurotrophins with the Trk receptors is specific: NGF binds with TrkA, BDNF and NT 4 both bind with TrkB, and NT 3 binds with the highest affinity to TrkC but is also capable of signaling through TrkA and TrkB. In addition to the full length TrkB receptor, several noncatalytic truncated TrkB isoforms have also been identified; these isoforms lack the signaling domain, preventing the induction of a signal transduction mechanism. Binding of a neurotrophin to the appropriate Trk receptor leads to the dimerization and transphosphorylation of tyrosine residues in the intracellular domain of the Trk receptors and subsequent activation of cytoplasmic signaling pathways..$^{50,51}$ All neurotrophins can bind to the pan75 neurotrophin receptor $\left(\mathrm{p} 75^{\mathrm{NTR}}\right.$ ), which plays a role in neurotrophin transport, ligand binding specificity, and Trk functioning. ${ }^{44,52,53}$

Of various neurotrophins, BDNF has attracted a great deal of interest as a functional candidate gene in various mental disorders. The $B d n f$ gene lies on the reverse strand of chromosome $11 \mathrm{p} 13$ and encodes a precursor peptide pro-BDNF. ${ }^{54}$ In fact, all neurotrophins, including BDNF, are synthesized as a pre-pro-neurotrophin precursor that undergo posttranslational modifications before giving rise to mature homodimeric protein. The pro-BDNF is produced in endoplasmic reticulum, which is accumulated in transGolgi network via Golgi apparatus. It has been suggested that pro-BDNF binds to sortilin in the Golgi, which facilitates the correct folding of the mature domain. The mature domain of BDNF binds to carboxypeptidase E, thereby sorting BDNF to the regulated secretary pathway. ${ }^{55} \mathrm{~A}$ substitution of valine (Val) to methionine (Met) at codon 66 in the 
prodomain impairs this sorting of BDNF. ${ }^{56}$ The pro-BDNF is the main form of neurotrophin, ${ }^{57-59}$ and the mature form originates through proteolytic cleaving. Plasmin is the major extracellular protease that cleaves pro-BDNF. ${ }^{60,61}$ The expression of the $B D N F$ gene is tightly regulated by neuronal activity, through mechanisms dependent on calcium. ${ }^{62}$ In addition to BDNF, the function of a receptor for BDNF (ie, TrkB) is also regulated in an activity-dependent manner. TrkB is primarily localized in the synaptic sites. Further localization of TrkB occurs at the synaptic sites after neuroanal activity. ${ }^{55}$ Neuronal activity, therefore, is critical for synthesis and intracellular targeting of TrkB receptors. ${ }^{55}$ Thus, BDNF release and expression of TrkB receptors in a coordinated fashion are important for optimal synaptic response.

The role of BDNF in depression has gained broad attention because many pre-clinical and clinical studies provide direct evidence suggesting that modulation in expression of BDNF could be involved in behavioral phenomenon associated with depression. Based on these studies, the neurotrophin hypothesis of depression was proposed, which suggests that stress and depression is associated with decreased expression of BDNF and that antidepressants alleviate depressive behavior by increasing its level. ${ }^{15,16}$ This is quite relevant given that BDNF is involved in synaptic plasticity and, as earlier mentioned, compromised synaptic and structural plasticity have been shown to be associated with depression. Because stress and depression are the major contributory factors in suicide, recently, a number of studies have attempted to investigate the role of BDNF in suicidal behavior. These studies, albeit in infancy, provide strong support for the idea that abnormalities in BDNF could be an important contributory factor in suicidal behavior. This review focuses on the critical assessment of the involvement of BDNF and its functioning in depression and suicidal behavior.

\section{BDNF in stress}

Several clinical and epidemiological studies have identified stressors as important risk factors in depression and suicide. ${ }^{63-70}$ An overactive hypothalamus-pituitary-adrenal axis has been well established in stress. On the other hand, there is strong evidence for a connection between stress system overactivity and suicidal behavior. For example, in suicide victims, hypothalamus-pituitary-adrenal axis hyperactivity has been linked with elevated corticotrophin-releasing hormone levels in the cerebrospinal fluid, reduced corticotrophinreleasing hormone binding sites in the frontal cortex, augmented pro-opiate-melanocortic RNA density in the pituitary, large corticotrophic cell size, and alterations in the mineralocorticoid to glucocorticoid receptor messenger RNA (mRNA) ratio in the hippocampus of suicide victims. ${ }^{71-76}$ Also, a consistent association has been found between subsequently completed suicide and nonsuppression of cortisol in the dexamethasone suppression test. ${ }^{77-82}$

Studies in pre-clinical models have shown stress-induced dysregulation of BDNF expression. Several types of stressors have been used to examine the role of BDNF in stress-related disorders. The very first study that examined the role of stress was from Smith and colleagues, ${ }^{83}$ who demonstrated that immobilization stress used for 1 or 7 days (for 2 hours per day) significantly decreased BDNF mRNA expression in the hippocampus. This decrease was present throughout the hippocampus; however, the dentate gyrus showed the most significant response. This was later confirmed by other investigators. ${ }^{84,85}$ Similar changes were observed when other types of stressors were used. For example, Rasmusson et al ${ }^{86}$ demonstrated that exposure to twenty 0.5 -second $0.4-\mathrm{mA}$ foot shocks coterminating with $70-\mathrm{dB}, 5$-second-long pure tones over 60 minutes decreased dentate gyrus BDNF mRNA. Some of the stressors, such as social defeat, decreased BDNF not only in hippocampus but also in cortical and subcortical areas of mice. ${ }^{87}$ Interestingly, it has been shown that maternal separation led to depression like behavior in adulthood, which was correlated with decreased BDNF expression. ${ }^{88}$ This study suggests that early developmental insult causes depression in later life, which is mediated through abnormalities in BDNF-mediated signaling.

Several studies have shown that exposure of exogenous corticosterone (to mimic the stress effect) also reduces BDNF expression in rodent hippocampus, similar to that observed in various pre-clinical stress models. ${ }^{83,89-91}$ Recently, we examined the effects of corticosterone treatment on BDNF expression in detail and found that the mRNA level of BDNF was not only decreased in the hippocampus but that the frontal cortex also showed significantly reduced expression of BDNF. ${ }^{92}$ This suggests that the effects of glucocorticoids on BDNF are not limited to the hippocampus; other brain areas are also equally affected. When endogenous corticosterone was removed by adrenalectomy, the level of BDNF in the hippocampus increased. ${ }^{89,93}$ On the other hand, dexamethasone replacement to adrenalectomized rats restored the level of BDNF to control levels. ${ }^{93}$ These studies demonstrate that expression of BDNF expression is regulated via glucocorticoids.

On a molecular level, BDNF is highly regulated. The rat $B d n f$ gene contains 4 separate promoters that are linked 
to 4 main transcript forms. ${ }^{94,95}$ Each transcript has 4 short 5 ' noncoding exons (I-IV) containing separate promoters and 1 shared 3' exon (exon V) encoding the mature BDNF protein. Although the biological significance of these BDNF transcripts is not clear, it appears that these transcripts can facilitate multi-level regulation of BDNF expression and may determine the tissue-specific expression. To examine the molecular basis of stress regulation of BDNF, we determined mRNA levels of exons I through IV. We observed that corticosterone selectively decreased the expression of transcripts II and IV, but not transcripts I or III, in both the frontal cortex and hippocampus. ${ }^{92}$ Two other recent studies suggest that immobilization stress decreases total BDNF expression, along with a specific decrease in exon IV in the hippocampus ${ }^{96}$ and hypothalamus. ${ }^{97}$ These studies suggest that the decrease of BDNF mRNA expression by glucocorticoids may be due to a decrease in expression of the specific BDNF transcripts that contain exons II and IV.

\section{BDNF in depression}

In addition to stress, several lines of evidence point to the involvement of BDNF in depression. These include indirect evidence demonstrating that antidepressants regulate $\mathrm{BDNF} /$ TrkB expression and that BDNF itself shows antidepressant-like effects. In addition, depressed patients show alterations in expression of BDNF both in blood cells and in postmortem brain tissues. Genetic studies also link BDNF polymorphism to depression. Each of these aspects are detailed further.

\section{Regulation of BDNF expression by antidepressants}

The effects of antidepressants on the expression of the $B d n f$ gene have been investigated extensively. In general, it has been shown that when given to healthy rodents, several classes of antidepressants, including monoamine oxidase inhibitors, selective serotonin reuptake inhibitors, tricyclic agents, noradrenaline reuptake inhibitors, and noradrenergic and specific serotonergic antidepressants, all increase expression of BDNF in the brain. ${ }^{98-108}$ In addition, several other agents known to have antidepressant properties also increase expression of BDNF in rodent brain. These agents include $\alpha$-amino-3-hydroxy-5-methyl-4-isoxazole propionic acid and $N$-methyl-D-aspartate antagonists, electroconvulsive shock, and transcranial magnetic stimulation..$^{98,109-114}$ Chronic treatment with antidepressants not only increases expression of BDNF in healthy rodents, but also reverses downregulation of BDNF caused by stress. ${ }^{98,115,116}$ However, these effects depend on various factors, including length of administration, class of antidepressant, route of administration, age of animal, and doses of the drugs. In general, an increase in BDNF expression occurs only after long-term treatment and, in most cases, short-term treatment with antidepressants causes no change in the expression of BDNF. ${ }^{98,101,106,117,118}$ However, short-term treatment with antidepressants has also been shown to cause an increase in BDNF expression in the cortex ${ }^{119,120}$ and even a decrease in the hippocampus. ${ }^{101,119,120}$

The effects of antidepressants such as desipramine or fluoxetine have also been studied in BDNF-deficient mice. These studies show that the behavioral effects of antidepressant are abolished in BDNF-deficient mice, ${ }^{121,122}$ suggesting that BDNF plays an important role in the behavioral effects of antidepressants.

\section{Regulation of BDNF exons by antidepressants}

To examine how BDNF is regulated in response to antidepressants, we administered different classes of antidepressants (serotonin uptake blocker, fluoxetine, norepinephrine blocker, desipramine, monoamine oxidase inhibitor, or phenelzine) to healthy rats and examined whether antidepressants regulate the expression of BDNF via specific BDNF transcript(s). ${ }^{92}$ We observed very interesting results such that treatment of healthy rats with desipramine or phenelzine increased mRNA levels of total BDNF in both the frontal cortex and hippocampus, whereas fluoxetine increased the mRNA level of BDNF only in the hippocampus. ${ }^{92}$ More interestingly, when we examined the effects of antidepressants on the expression of individual exons containing BDNF transcripts, we found that desipramine specifically increased exons I and III in both the frontal cortex and hippocampus; fluoxetine increased only exon II in the hippocampus; and phenelzine effectively increased exons I and IV in the hippocampus but only exon I in the frontal cortex. In another study, Dias et al ${ }^{102}$ examined the effects of long-term antidepressants on BDNF transcript levels in the rat hippocampus, amygdala, and cortex. They observed that desipramine increased exon III in different cortical areas, whereas fluoxetine had no significant effects on BDNF exons in any of the brain areas studied. Another recent study by Altieri et $\mathrm{al}^{118}$ also showed no effect of long-term fluoxetine treatment on BDNF transcripts in the hippocampus. Our observation of increased exon III by desipramine is similar to the findings of Dias et $\mathrm{al}^{102}$ but we also noted an increase in the expression of exon I. In addition, contrary to reports 
by Dais et $\mathrm{a}^{102}$ and Altieri et al ${ }^{118}$ we found a selective increase in exon II by fluoxetine in both the frontal cortex and hippocampus. Although some of these discrepancies can be attributed to route of administration or doses of drugs, these findings suggest that there is no unified mechanism for the regulation of BDNF exon(s) by antidepressants and that various classes of antidepressants may affect BDNF exon expression differently.

We further examined whether antidepressants reverse the corticosterone-mediated decrease in BDNF and whether similar BDNF exons are involved in this mechanism by which antidepressants upregulate BDNF expression. ${ }^{92} \mathrm{We}$ observed that long-term treatment with desipramine completely reversed the corticosterone-induced decrease in BDNF in both the frontal cortex and hippocampus. Fluoxetine was able to partially reverse the changes in hippocampal BDNF, but did not cause any change in the frontal cortex. Phenelzine, on the other hand, reversed the corticosterone-induced decrease in BDNF partially in the frontal cortex and completely in the hippocampus. Interesting results were noted when individual BDNF transcripts were examined after antidepressant treatment of corticosterone-implanted rats: the antidepressants were able to increase mRNA levels of only those BDNF transcripts that were affected when the respective antidepressant was given to healthy rats without corticosterone pellet implantation. Thus, desipramine increased exons I and III in the frontal cortex and hippocampus, fluoxetine increased exon II in the hippocampus, and phenelzine increased exon I in the frontal cortex and exons I and IV in the hippocampus. Surprisingly, except for the changes in exon II by fluoxetine in the frontal cortex and in exon IV by phenelzine in the hippocampus, the corticosterone-mediated decrease in exons II and IV persisted even after antidepressant treatment. However, the overall observation was that all the antidepressants increased the level of total BDNF mRNA in the brain of corticosterone-treated rats. Although it is difficult to assess the extent of involvement of a particular exon in regulation of overall BDNF expression, there is complete reversal by desipramine in both the frontal cortex and hippocampus because the increase in exon III was very robust in these brain areas. On the other hand, in the hippocampus, fluoxetine was able to reverse the corticosterone-mediated decrease of only exon II, but not exon IV; therefore, the reversal was partial. However, no effect of fluoxetine on total BDNF expression was observed in the frontal cortex, because fluoxetine was not able to increase either exon II or IV in the frontal cortex. On the other hand, phenelzine was partially effective in the frontal cortex because of its effects on exon II, but complete reversal was noted in the hippocampus because phenelzine increased the levels of both corticosterone-decreased exons II and IV. Thus, it appears that antidepressants are effective in causing an increase in total BDNF expression in corticosterone-treated rats; however, the mechanisms for the down-regulation of BDNF transcripts by corticosterone and those that affect their upregulation by antidepressants are quite different.

\section{TrkB studies in relation to antidepressant treatment}

In addition to BDNF, TrkB receptors have also been studied in relation to antidepressant treatment. The Trkb gene can give rise to at least 2 isoforms of TrkB, encoding the "fulllength," or catalytic, form of TrkB, the receptor mediating the main biological actions of BDNF, ${ }^{123,124}$ and the "truncated" TrkB receptors (TrkB.T1), which lack a large part of the intracellular domain and do not display protein-tyrosine kinase activity. ${ }^{125}$ Binding with BDNF leads to activation of the full-length TrkB receptors by ligand-induced dimerization and autophosphorylation of tyrosine residues in the intracellular region. ${ }^{126}$ Full-length TrkB receptors also mediate retrograde transport of BDNF to neuronal cells. ${ }^{127}$ The activated receptors become able to interact and phosphorylate several intracellular targets. Although catalytic TrkB is considered as the receptor mediator of the main biological actions of BDNF, the truncated TrkB is also a predominant isoform in the adult brain, ${ }^{128,129}$ functioning as a cellular adhesion molecule regulating synaptic plasticity and axonal outgrowth, modulating signaling by catalytic TrkB through the formation of heterodimers, and regulating the extracellular availability of its endogenous ligands. ${ }^{125}$ It has been shown that BDNF signaling is impaired as a consequence of the formation of receptor heterodimers, ${ }^{130}$ which suggests that the truncated form of TrkB can act as a negative modulator of BDNF signaling.

It has been shown that long-term treatment with electroconvulsive shock, desipramine, fluoxetine, tranylcypromine, and sertraline all increased mRNA levels of TrkB in the rat brain. ${ }^{98}$ Recently, Rantamäki et al ${ }^{131,132}$ reported that not only the expression, but TrkB signaling, is rapidly activated by a variety of antidepressants in mouse medial prefrontal cortex (PFC) and hippocampus. This occurs through antidepressantmediated autophosphorylation of TrkB. These studies suggest that the behavioral effect of antidepressants requires TrkB activation along with an increase in BDNF expression. Interestingly, the TrkB-mutant mice do not exhibit depression-like behaviors such as increased "despair" in 
the forced swim test. ${ }^{133}$ However, TrkB.T1-overexpressing transgenic mice, which show reduced TrkB activation in the brain, and heterozygous BDNF null (BDNF+/-) mice both are resistant to the effects of antidepressants in the forced swim test, indicating that normal TrkB signaling is required for the behavioral effects typically produced by antidepressants. ${ }^{121}$

\section{Antidepressant-like effect of BDNF}

The role of BDNF in depression also stems from preclinical studies demonstrating that BDNF not only regulates expression of BDNF but shows antidepressant-like effects in animal models. In a learned helplessness model of depression, infusion of BDNF reduces escape latencies and failure rates in rodents, ${ }^{134,135}$ suggesting the effectiveness of BDNF in reducing inescapable random shock-induced depressive behavior. Similarly, intra-midbrain infusion of BDNF in rodents produces antidepressant-like effect in the forced swim test and learned helpless models of depression. ${ }^{134}$ Infusion of BDNF in the dorsal raphe nucleus also resulted in antidepressant-like effect in the learned helpless model of depression. ${ }^{136}$ Interestingly, the effects of BDNF on these behavioral paradigms were much longer lasting compared with classic antidepressants. ${ }^{135,137}$

\section{Clinical studies of BDNF response in depressed patients before and after antidepressant treatment}

Consistent with animal studies, studies in humans provide evidence that BDNF plays an important role in depression. Although BDNF is highly expressed in the brain, studies regarding the expression level of BDNF in the human brain of depressed subjects are limited. In an earlier study, Chen et $\mathrm{al}^{138}$ showed that the expression of BDNF is increased in the postmortem brain of depressed subjects treated with antidepressants compared with those who were untreated. Recently, many studies have attempted to examine the level of BDNF in serum or platelets of depressed subjects with and without antidepressant treatment. Although the significance of measurement of BDNF in blood cells is unclear, it was demonstrated that BDNF may cross the blood-brain barrier and that platelet BDNF shows similar changes postnately similar to the brain, ${ }^{139}$ suggesting that there are parallel changes in the blood and brain levels of BDNF. Karege and colleagues ${ }^{140}$ were the first to compare BDNF levels in the serum of depressed subjects and healthy controls. In 15 male and 15 female depressed patients, they found that BDNF level was significantly lower compared with healthy controls. This decrease was negatively correlated with the severity of depression. Moreover, they found a sex effect such that female depressed patients were more severely depressed and released less BDNF than males. Recently, the same group of investigators suggested that the decrease in serum BDNF in depressed patients is related to release mechanisms of BDNF because no change was found in the level of BDNF in blood, but serum and platelet BDNF were decreased in depressed patients. ${ }^{141}$ Since then, several studies have examined BDNF level in these peripheral tissues before and after antidepressant treatment. For example, Gonul et $\mathrm{al}^{142}$ and Piccinni et al ${ }^{143}$ reported decreases in serum BDNF level in depressed patients. On the other hand, Matrisciano et $\mathrm{al}^{144}$ examined serum BDNF levels in healthy subjects and depressed patients at baseline and after 5 weeks and 6 months of sertraline, escitalopram, or venalfaxine treatment. They found that the BDNF level was lower in depressed patients and that sertraline increased BDNF level after 5 weeks and 6 months, whereas escitalopram increased BDNF level only after 6 months. Venalfaxine did not change the level of BDNF. There was a negative correlation between increase in BDNF level and decrease in Hamilton Depression Rating Scale score. On the other hand, Gonul et al ${ }^{142}$ reported that depressed patients show increased BDNF level in serum after treatment with a variety of antidepressants for 8 weeks, including venalfaxine, sertraline, fluoxetine, paroxetine, and citalopram. Similarly, increases in serum BDNF level by amitriptyline after 36 days, paroxetine after 4 or 8 weeks, or venalfaxine after 12 weeks of treatment to depressed patients were reported. ${ }^{145-147}$ Not only antidepressants but vagus nerve stimulation, repetitive transcranial magnetic stimulation, ${ }^{148}$ or electroconvulsive therapy ${ }^{149}$ to depressed patients also cause an increase in serum BDNF level in depressed patients. In a recent meta-analysis, Brunoni et $\mathrm{al}^{150}$ and Sen et al ${ }^{151}$ concluded that BDNF levels are lower in depressed patients than healthy controls and that BDNF levels are significantly higher after antidepressant treatment. Overall, these findings provide strong evidence of modulation in BDNF in depression and in response to antidepressants.

\section{Role of BDNF in genetic basis of depression}

The gene encoding human BDNF is localized at chromosome 11p13. In humans, a common single nucleotide polymorphism at nucleotide 196 within the 5' pro-BDNF sequence encodes a variant BDNF at codon 66 (Val66-Met). As mentioned earlier, this Met66 variant affects activity-dependent BDNF secretion. ${ }^{56,59}$ This is critical for dendritic trafficking and synaptic localization of BDNF. Interestingly, knockout 
mice carrying the Val66Met polymorphism show reduced activity-dependent secretion of BDNF, without any change in the level of total BDNF. ${ }^{152}$ More interestingly, mice carrying the BDNF Met/Met or Val/Met allele show a reduced volume of hippocampus compared with wild-type mice, and BDNF Met/Met knock-in mice have reduced dendritic arbor complexity. ${ }^{152}$ These studies are quite relevant to depression, because structural abnormalities, particularly structural abnormalities in the brain, including reduced hippocampal volume during stress and in depressed patients, have been reported, ${ }^{153,154}$ which increases the risk for depression. Recently, Frodl et al ${ }^{155}$ examined the effect of the BDNF Val66Met polymorphism on hippocampal and amygdala volumes in patients with depression and in healthy control subjects. They found that depressed patients had significantly reduced hippocampal volumes. They also found smaller hippocampal volumes for depressed patients and for healthy controls carrying the Met-BDNF allele when compared with subjects homozygous for the Val-BDNF allele. No significant difference in amygdala volume was found between depressed patients and healthy controls and no significant main effects for the BDNF Val66Met polymorphism were observed. They concluded that the Met-BDNF allele carriers might be at risk of developing smaller hippocampal volumes and might be susceptible to depression. Interestingly, human magnetic resonance imaging studies in normal healthy subjects showed that $\mathrm{Val} / \mathrm{Val}$ homozygotes had a larger hippocampal volume than Val/Met heterozygotes. ${ }^{156-158}$

People with the Met allele also have poor hippocampaldependent memory function and hippocampal hyperactivation during learning, ${ }^{56,159}$ which could be associated with hippocampal hypersensitivity to stress. On the other hand, Kliem et al ${ }^{160}$ demonstrated that training-dependent increases in the amplitude of motor-evoked potentials and motor map reorganization are reduced in healthy subjects with a Val66Met polymorphism in the $B d n f$ gene, compared with subjects without the polymorphism. These results suggest that BDNF is involved in mediating the experiencedependent plasticity of the human motor cortex. Furthermore, the Val66Met polymorphism in the $B d n f$ gene modulates human cortical plasticity and the response to transcranial magnetic stimulation. ${ }^{161}$

Earlier, Tsai et al ${ }^{162}$ studied the $B d n f$ gene Val66Met polymorphism in 152 patients with MDD and in 255 healthy controls. They also examined the association of this polymorphism and fluoxetine therapeutic response in 110 patients with MDD who received a 4-week fluoxetine treatment. They found no significant differences for the genotype or allele frequency of the BDNF polymorphism comparing the MDD and control groups. Further, no significant differences were noted comparing the 3 genotype groups for depressive-cluster symptoms. However, a trend to improved 4-week fluoxetine antidepressant response was demonstrated for heterozygous patients compared with homozygous analogs. Similarly, Choi et al ${ }^{163}$ reported that the genotype, allele, and allele-carrier distributions for the Val66Met polymorphism did not differ significantly between patients with MDD and healthy controls; however, they showed that the Val66Met polymorphism of BDNF was associated with citalopram efficacy, with Met-allele carriers responding better to citalopram treatment.

Very recently, Licinio et al ${ }^{164}$ studied novel genetic polymorphisms in the BDNF gene and assessed their frequencies and associations with MDD or antidepressant response. They identified 83 novel single-nucleotide polymorphisms (SNPs): 30 in untranslated regions, 4 in coding sequences, 37 in introns, and 12 in upstream regions; 3 of 4 rare novel coding SNPs were nonsynonymous. Association analyses of patients with MDD and controls showed that 6 SNPs were associated with MDD (rs12273539, rs11030103, rs6265, rs28722151, rs41282918, and rs11030101) and 2 haplotypes in different blocks (one including Val66, another near exon VIIIh) were significantly associated with MDD. One recently reported 5' untranslated region SNP, rs61888800, was associated with antidepressant response.

Hwang et al ${ }^{165}$ reported that the BDNF Val66Met genotype distribution was significantly different between geriatric depressed patients and healthy subjects and there was a significant excess of the Met allele in these patients compared with the control group. Very recently, Duncan et $\mathrm{al}^{166}$ found that the $\mathrm{Val} / \mathrm{Val}$ genotype was associated with higher scores on the Cognitive-Affective factor of the Beck Depression Inventory-II, Cognitive-Affective factor scores, and Somatic-Vegetative factor scores, suggesting an association between the $\mathrm{Val} / \mathrm{Val}$ genotype and higher levels of depression symptoms. In a similar line of investigation, Savitz et $\mathrm{al}^{167}$ showed that bipolar patients, who were metallele carriers, and were exposed to sexual abuse, performed more poorly on memory test, suggesting that functional BDNF polymorphism and cognition would moderate the effect of psychological trauma on memory. Similar findings were later reported by other investigators. ${ }^{168,169}$ Interestingly, Childhood adversity per se predict higher levels of adult depressive symptoms and BDNF Val66Met polymorphisms moderate the effect of childhood sexual abuse on adult depressive symptoms. ${ }^{170}$ 
Another piece of evidence demonstrating role of BDNF in depression comes from studies showing an association of personality traits and BDNF polymorphism. ${ }^{171-174}$ It is pertinent to mention that personality traits have been linked to major depression as well as suicide. ${ }^{175}$

\section{Do epigenetics play any role in BDNF modification in depression and antidepressant responses?}

Recent studies suggest that epigenetic regulation of the gene may be crucial in the pathophysiology of depressive behavior. ${ }^{176}$ Histone modifications along with DNA methylation play a major role in gene silencing through chromatin remodeling. Methyl-CpG binding protein $\mathrm{MeCP}$, which encodes a protein that functions as a transcriptional repressor, selectively binds to BDNF promoter III and represses expression of the $B d n f$ gene. Membrane depolarization triggers the calcium-dependent phosphorylation and release of $\mathrm{MeCP} 2$ from $\mathrm{BDNF}$ promoter III, thereby facilitating transcription. ${ }^{177}$ On the other hand, membrane depolarization causes increased BDNF transcription, which involves dissociation of the MeCP2-histone deacetylase-mSin3A repression complex from its promoter, ${ }^{177,178}$ which suggests that DNA methylation-related chromatin remodeling is important for activity-dependent $B d n f$ gene regulation. Recently, Fuchikami et a ${ }^{179}$ reported that single immobilization stress (a model for depression) decreased the levels of BDNF mRNA, which was associated with decreased expression of exons I and IV. They also reported that the levels of acetylated histone $\mathrm{H} 3$ were decreased in the promoters of I, IV, and VI exons, suggesting that histone acetylation is involved in regulation of the $B d n f$ gene in the immobilization stress model. Earlier, in an important study, Tsankova et $\mathrm{al}^{180}$ found that social defeat stress caused down-regulation of BDNF exons III and IV and robustly increased histone methylation at their corresponding promoters. Long-term imipramine treatment reversed this downregulation and increased histone acetylation at these promoters. This hyperacetylation by long-term imipramine treatment was associated with a selective down-regulation of histone deacetylase. Overexpression of HDAC5 blocked the ability to reverse depression-like behavior. Altogether, these studies suggest that although BDNF expression is repressed or induced by stress or antidepressants by different mechanisms, epigenetic regulation of the $B D N F$ gene plays an important role in depression and in the mechanisms of action of antidepressants.

\section{BDNF in suicide}

Because depression is an important causative factor in suicidal behavior, it is interesting to examine whether suicidal behavior is associated with alterations in BDNF and its cognate receptors. It is more interesting to examine whether alterations in BDNF in suicidal subjects are independent of depression. In this regard, postmortem brain studies in suicide subjects with or without depression, levels of BDNF in blood cells of suicidal patients, and genetic association studies linking BDNF to suicide have been performed. These studies indicate a possible role of BDNF to suicidal behavior.

\section{Human postmortem brain studies}

To my knowledge, we were the first to examine of the role of BDNF in suicide. We determined $\mathrm{mRNA}$ and protein expression of BDNF in the PFC (Brodmann's area 9) and hippocampus from specimens obtained from 21 fully characterized suicide subjects and 27 nonpsychiatric healthy control subjects. ${ }^{181} \mathrm{We}$ observed that mRNA level of BDNF was significantly reduced, independently and as a ratio to neuron-specific enolase (a housekeeping gene), in both the PFC and hippocampus of suicide subjects compared with nonpsychiatric healthy control subjects. These reductions were associated with a significant decrease in the protein level of BDNF. Interestingly, when we divided suicide subjects into those who had depression and those who had another psychiatric disorder, we found that the decrease in expression of BDNF was present in all suicide subjects regardless of psychiatric diagnosis. Our findings demonstrate that suicidal behavior may be associated with a decrease in BDNF functioning. More recently, Karege et al ${ }^{182}$ examined the expression of BDNF in the PFC, hippocampus, and entorhinal cortex in suicide subjects. Similar to our findings, they reported that the level of BDNF was significantly decreased in the PFC and hippocampus. No change was found in the entorhinal cortex, suggesting that a decrease in BDNF may be specific only to certain brain areas. In addition, Karege et $\mathrm{al}^{182}$ found that suicide subjects who were receiving antidepressant treatment did not show any change in the level of BDNF, suggesting that psychotropic drugs normalize the decreased level of BDNF in suicide subjects. Interestingly, Kozcicz et al ${ }^{183}$ reported sex-specific changes in the level of BDNF in suicide subjects. They found that BDNF level was much lower in the midbrain (nonpreganglionic EdingerWestphal nucleus) of male suicide subjects, whereas female suicide subjects showed an increased level of BDNF in this brain area, suggesting a possible sex effect in the regulation of BDNF expression in suicide subjects. Although the previous studies did not find sex-specific changes in BDNF expression in the hippocampus or cortical areasb, ${ }^{181,182}$ whether sexspecific effect in BDNF expression is specific to the midbrain area needs further studies. 
In addition to adult suicide subjects, we recently examined the expression of BDNF in postmortem brain samples obtained from teenaged suicide subjects. ${ }^{184}$ Protein and mRNA expression of BDNF was determined in samples from the PFC, Brodmann's area 9, and hippocampus obtained from 22 teenaged suicide victims and 22 matched nonpsychiatric healthy control subjects. As with adult suicide subjects, we found that protein expression of BDNF was significantly decreased in the PFC of teenaged suicide subjects. Interestingly, no significant change in BDNF protein expression was observed in the hippocampus. On the other hand, a decrease in BDNF mRNA was observed both in the PFC and hippocampus of teenaged suicide subjects. Whether this subtle difference in the protein expression of BDNF represents differences in some characteristics between teenage and adult suicide is not clear. Nonetheless, this study further suggests that BDNF is involved in suicidal behavior.

\section{Blood cell studies}

As in depressed patients, the BDNF level in blood cells has also been examined in patients with suicidal ideation or in those who have attempted suicide. Deveci et al ${ }^{185}$ investigated whether their serum BDNF levels differ among suicide attempters without a major psychiatric disorder compared with patients with MDD and healthy subjects. Ten suicide attempters, 24 patients with MDD, and 26 subjects without any psychiatric diagnosis and any psychiatric treatment were examined. They found that serum BDNF levels were lower in both the attempted suicide group and the MDD group vs the control group. In another study, Kim et al ${ }^{186}$ measured plasma BDNF levels in 32 depressed patients who had recently attempted suicide, 32 nonsuicidal depressed patients, and 30 healthy controls. They found that BDNF levels were significantly lower in suicidal depressed patients than nonsuicidal depressed patients or healthy controls. Interestingly, BDNF levels were not different between fatal and nonfatal suicide attempts. Similarly, Lee et a ${ }^{187}$ found that plasma BDNF level was decreased in depressed suicidal patients vs depressed nonsuicidal patients. These studies suggest that reduction of plasma BDNF level is related to suicidal behavior in depression and that BDNF level may be a biological marker of suicidal depression. However, when BDNF level was determined in platelets, it was found that platelet BDNF levels were lower in both nonsuicidal and suicidal depressed patients compared with healthy controls, whereas no significant differences were noted between nonsuicidal and suicidal depressed patients. ${ }^{188}$ Interestingly, Dawood et al ${ }^{189}$ used direct internal jugular vein blood sampling methods to circumvent the issue of whether BDNF is released from other sources than the brain and they examined the relationship between brain BDNF production and suicide risk in untreated patients with depression. They used veno-arterial BDNF plasma concentration gradient as an index of brain BDNF production. Of the patients, 11 had low suicide risk and 8 had a moderate to high suicide risk. The veno-arterial BDNF concentration gradient was significantly reduced in patients at medium to high suicide risk and there was a significant negative correlation between suicide risk and the internal jugular venous veno-arterial BDNF concentration gradient. This study suggests an association between internal jugular venous BDNF overflow and suicide risk.

\section{Genetic studies linking BDNF to suicide}

Hong and colleagues ${ }^{190}$ were the first to study an association of BDNF with suicide. They did not find any significant association of Val66Met polyorphism and suicidality in bipolar patients of Chinese origin. Recently, Kim et a ${ }^{191}$ examined BDNF Val/Met polymorphism in bipolar disorder in Korean subjects and whether clinical features vary according to genotype. They found that allelic distributions did not differ significantly between bipolar patients and healthy normal controls; however, the rate of suicide attempts among the $\mathrm{Val} / \mathrm{Val}$, $\mathrm{Val} / \mathrm{Met}$, and Met/Met genotype groups was significantly different. Relative to patients with the $\mathrm{Val} / \mathrm{Val}$ genotype, those with the Met/Met genotype had a 4.9-fold higher risk of suicide attempts, suggesting that BDNF Val/Met is related to the suicidal behavior in bipolar patients. On the other hand, Sarchiapone et al ${ }^{192}$ genotyped 170 depressed patients for their history of suicide attempts and BDNF Val/Met polymorphism. Depressed patients who carried the BDNF Val/Met polymorphism variant $(\mathrm{GA}+\mathrm{AA})$ showed significantly increased risk of suicidal behavior. The risk of a suicide attempt was also significantly higher among those reporting higher levels of childhood emotional, physical, and sexual abuse. Secondary analyses suggested that depression severity was a significant risk factor only in the wild-type BDNF genotype, and that the risk of suicide attempts was more predictable within the wild-type group. The same group of investigators extended this study in postmortem samples of subjects who completed suicide and healthy controls. ${ }^{193}$ They did not find a significant association of BDNF Val/Met polymorphism with suicide. They argued that even if family studies showed a shared inheritability of suicidal tendencies between suicide attempters and completers, completed suicide and attempted suicide may have two distinct phenomena 
and different molecular genetic components may be involved. They also analyzed two other polymorphisms in the $B d n f$ gene, $-270 \mathrm{C}>\mathrm{T}$ and $-281 \mathrm{C}>\mathrm{A}$, and found their occurrence as less than 5\%. Interestingly, Perroud et a ${ }^{194}$ examined whether a Val/Met BDNF polymorphism could moderate the effect of childhood maltreatment on the onset, number, and violence of suicidal behavior in suicide attempters. They reported that childhood sexual abuse was associated with violent suicide attempts in adulthood only among $\mathrm{Val} / \mathrm{Val}$ individuals and not among $\mathrm{Val} / \mathrm{Met}$ or Met/Met individuals. The severity of childhood maltreatment was significantly associated with a higher number of suicide attempts and with a younger age at onset of suicide attempt. This result suggests that Val/Met modulates the effect of childhood sexual abuse on the violence of suicidal behavior and that BDNF dysfunction may enhance the risk of violent suicidal behavior in adulthood. Altogether, these studies clearly link BDNF polymorphisms to suicidal behavior.

\section{TrkB studies in suicide}

Apart from BDNF, TrkB receptors have also been studied in relation to suicidal behavior. We examined the expression levels of TrkB in the same postmortem brain samples in which we determined the expression levels of BDNF. We found that the expression of full-length TrkB was significantly decreased in the PFC and hippocampus of suicide subjects compared with nonpsychiatric healthy controls. Interestingly, we did not find changes in expression of truncated isoform of TrkB (TrkB.T1). We found similar changes in PFC and hippocampus of teenaged suicide subjects. ${ }^{184}$ Our finding of decreased full-length TrkB expression in the suicide brain specimen may have serious implications. The decrease in full-length TrkB would not only affect BDNF-induced signaling but also the supply of BDNF to neurons and, thus, the loss of trophic maintenance of a variety of neuronal types, because the catalytically active full-length TrkB is present predominantly within neuronal axons, cell soma, and dendrites. ${ }^{195}$ In addition, the undiminished numbers of truncated TrkB would only exacerbate any effects as a result of the loss of catalytically active full-length TrkB, because truncated TrkB inhibits BDNF-mediated neurite outgrowth via the internalization of BDNF. More recently, we examined the functionality of full-length TrkB. We found that tyrosine phophorylation of TrkB was significantly compromised in the brain specimens of suicide subjects. ${ }^{196}$ These studies suggest that not only BDNF and TrkB are less expressed, but the functioning of TrkB is also impaired, in suicide brain specimens.
In a recent study, Ernst et al ${ }^{197}$ studied truncated TrkB (TrkB.T1) in frontal cortical regions and the cerebellum of suicide subjects. They found that about $36 \%$ of suicide completers had significant decreases in different probe sets specific to TrkB.T1 in frontal cortical areas but not the cerebellum. The decrease in TrkB expression was specific to the T1 splice variant. There was no effect of genetic variation in a 2500-base pair promoter region or at relevant splice junctions; however, an effect of methylation state at particular CpG dinucleotides on TrkB.T1 expression was noted. These results suggested a reduction in TrkB.T1 expression in suicide subjects, which was associated with the epigenetic modification of the TrkB.T1 promoter region.

\section{P75 ${ }^{\text {NTR }}$ studies in suicide}

$\mathrm{p} 75^{\mathrm{NTR}}$, initially discovered as a low-affinity receptor for NGF, is now known as a class of receptor that can bind to all neurotrophins with equivalent nanomolar affinities. ${ }^{198}$ The 3.8-kb mRNA for $\mathrm{p} 75^{\mathrm{NTR}}$ encodes a 427 -amino acid protein containing a 28 -amino acid single peptide, a single transmembrane domain, and a 55-amino acid cytoplasmic domain. ${ }^{199}$ Although $\mathrm{p} 75^{\mathrm{NTR}}$ receptors do not contain a catalytic motif, they interact with several proteins, including Trk receptors, which causes enhancement of ligand specificity and ligand affinities for Trk receptors. ${ }^{200-202}$ Functionally, in contrast to Trk receptors, which contain autophosphorylation sites and are involved in cell survival, p $75^{\text {NTR }}$ lacks intrinsic enzymatic activity and can transmit both positive and negative signals. ${ }^{203}$ It has been shown that $\mathrm{p} 75^{\mathrm{NTR}}$ can mediate neuronal apoptosis when the cognate Trk receptor is less activated or not activated. ${ }^{204}$ Similarly, p75 $5^{\text {NTR }}$ can cause developing hippocampal neuronal death induced by neurotrophins in the absence of a Trk receptor. ${ }^{205-207}$ In the adult CNS, it has been shown that excitotoxin-induced neuronal apoptosis is accompanied by the induction of $\mathrm{p} 75^{\mathrm{NTR}}$ in the dying neurons, ${ }^{208}$ which suggests that $\mathrm{p} 75^{\mathrm{NTR}}$ may represent a general stress-induced apoptotic mechanism. ${ }^{209}$ However, the apoptotic mechanisms of $\mathrm{p} 75^{\mathrm{NTR}}$ are active only when Trk receptors are less expressed or less active. Moreover, ectopic expression of the appropriate Trk receptor can convert a proapoptotic neurotrophin to a prosurvival neurotrophin. Thus, it appears that the ratio of expression levels and/or activation states of Trk receptors and $\mathrm{p} 75^{\mathrm{NTR}}$ is quite relevant in neurotrophin-mediated functions. Recently, we observed that the expression ratio of $\mathrm{p} 75^{\mathrm{NTR}}$ to Trk receptors is increased in the postmortem brain specimens of suicide subjects. Reduced expression of neurotrophins ${ }^{181,210}$ together with reduced expression and activation of Trk and 
concomitant increased expression of $\mathrm{p} 75^{\mathrm{NTR}}$ indicate that the possible consequence is a tipping of the balance away from cell survival, which could be associated with structural abnormalities and reduced neuronal plasticity in suicide brain specimens.

The two major signaling pathways activated by Trks are Ras-Raf extracellular signal-regulated kinase (ERK) and phosphoinositide 3-kinase (PI3-kinase)-Akt. In addition, phospholipase $\mathrm{C} \gamma$ binds to activated Trk receptors and initiates an intracellular signaling cascade that results in the activation of protein kinase $\mathrm{C}$. On the other hand, $\mathrm{p} 75^{\mathrm{NTR}}$ stimulates several proapoptotic pathways, which include C-Jun kinase signaling, sphingolipid turnover, and association with adaptor proteins, such as neurotrophin receptor-interacting MAGE homolog (NRAGE) and p75 ${ }^{\mathrm{NTR}}$-associated cell death executor (NADE), that directly promote cell cycle arrest and apoptosis. ${ }^{211-214}$ Trk receptors suppress the major proapoptotic signaling pathway, c-Jun kinase, initiated by $\mathrm{p} 75^{\mathrm{NTR}} \cdot{ }^{215}$ In sympathetic neurons, Ras-mediated activation of PI3-kinase is required to suppress this signaling pathway. ${ }^{216}$ Activation of Trk receptors completely suppresses the activation by $\mathrm{p} 75^{\mathrm{NTR}}$ of sphingomyelinase through the association of activated PI3-kinase with acidic sphingomyelinase. ${ }^{217,218}$ Sphingomyelinase activation results in generation of ceramide, which promotes apoptosis by inactivating ERK and PI3-kinase pathways. ${ }^{219-221}$ Interestingly, we have reported less-activated ERK1/2 222,223 and PI-3 kinase ${ }^{224}$ in both the PFC and the hippocampus of suicide subjects. These findings could be associated with less activation/expression of Trks. These findings also indicate suboptimal activation of prosurvival pathways. Conversely, if $\mathrm{p} 75^{\mathrm{NTR}}$ is more abundantly expressed, this may lead to proapoptotic signaling. Further studies are required to determine whether proapoptotic pathways are activated in the brain specimens of suicide subjects and how Trk- and p $75^{\mathrm{NTR}}$-mediated signal transduction pathways interplay in the pathophysiology of suicide.

Recently, it has been shown that pro-BDNF binds preferentially to $\mathrm{p} 75^{\mathrm{NTR}}$ and elicits apoptosis as opposed to mature BDNF, which binds weakly with $\mathrm{p} 75^{\mathrm{NTR}}$ but with high affinity to $\operatorname{TrkB}$, where it exerts neuroprotective activity. ${ }^{60,225}$ Thus, pro-BDNF and mature BDNF cause opposite physiological actions through binding to $\mathrm{p} 75^{\mathrm{NTR}}$ and TrkB receptors, respectively. ${ }^{55}$ In fact, it has been shown that pro-BDNF facilitates long-term depression via activation of $\mathrm{p} 75^{\mathrm{NTR}} \cdot{ }^{226}$ On the other hand, TrkB plays a critical role in early-phase long-term potentiation ${ }^{227}$ and conversion of pro-BDNF to mature BDNF is essential for TrkB-mediated late-phase long-term potentiation. ${ }^{61}$ In a recent preliminary study, we observed that the level of pro-BDNF is increased PFC and hippocampus of suicide subjects (unpublished observation), whereas a recent genetic study suggests that the S205L polymorphism, which substitutes a serine with a leucine residue, of the $\mathrm{p} 75^{\mathrm{NTR}}$ gene is associated with attempted suicide. ${ }^{228}$ These studies reveal the crucial roles of pro-BDNF and $\mathrm{p} 75^{\mathrm{NTR}}$ in suicidal behavior.

\section{Conclusion and future studies}

Several preclinical and clinical observations indicate that depression may be associated with the inability of neural systems to exhibit adaptive plasticity. Given the role of BDNF and its cognate receptors in neural and structural plasticity, and that depression and antidepressants exert opposite actions on BDNF and TrkB expression and functions, it is apparent that BDNF signaling may be crucial in the pathophysiology of depression and in the mechanism of action of antidepressants. It is still unclear how a decrease in BDNF expression leads to depression. Genetic BDNF knock-in and knock-out models could possibly answer this question. However, recent studies suggest that a reduction in BDNF level in BDNF heterozygous knockout mice does not produce depression-like symptoms, ${ }^{229}$ although overexpression of TrkB reduces anxiety and depressive behavior in mice..$^{230,231}$ On the other hand, overexpression of TrkB.T1 fails to induce a depression-like effect in the forced swim test. ${ }^{121}$ Thus, more in-depth studies are required to answer this question.

For suicidal behavior, the studies showing abnormalities in BDNF signaling in suicide are compelling. Many postmortem brain studies in patients who complete suicide and in those with suicidal ideation or attempted suicide show decreased BDNF expression and abnormalities in its cognate TrkB/ TrkB.T1 receptor. Although depression is an important factor in suicide, some studies were able to differentiate suicidal behavior vs depressive behavior in terms of decreased level of BDNF. Genetic studies also indicate an association of BDNF to suicidal behavior. Not only BDNF, but signaling mechanisms to which BDNF mediates its functions are also impaired in the brain specimens of suicide subjects. From these studies, it can be assumed that a decrease in BDNF in suicide subjects is independent of psychiatric illness and stress diathesis; however, further studies will be required to answer this complex question.

There are many avenues in BDNF research in depression/ suicide that need further attention. For example, what role does dendritic localization of BDNF/TrkB play in altered plasticity in these disorders? What is the significance of enhanced 
expression of pro-BDNF and $\mathrm{p} 75^{\mathrm{NTR}}$ in the development of depressive/suicidal behavior? Recently, it has been shown that BDNF and TrkB regulate translational machinery in dendrites. ${ }^{232}$ Moreover, BDNF induces the expression of Lim kinase 1, a protein kinase whose mRNA translation is inhibited by brain-specific microRNA-134. microRNA 134 is localized in dendrites and its overexpression leads to a decrease in spine size through repression of Lim kinase 1 mRNA translation. ${ }^{233}$ Thus, studying BDNF/TrkB and other interacting proteins in dendrites will further reveal their novel mechanistic roles in the development of depression/suicidal behavior.

\section{Acknowledgments and disclosures}

This research was supported by grants from National Institute of Mental Health (R0168777, R21MH081099, R01MH82802), the National Alliance for Research in Schizophrenia and Depression, and the American Foundation for Suicide Prevention (Dr Y Dwivedi). The author has no conflicts of interest to disclose.

\section{References}

1. World Health Organization. The global burden of disease. Geneva, Switzerland: World Health Organization Press, 1996.

2. Blazer DG. Mood disorders: epidemiology, in Comprehensive Textbook of Psychiatry, Sadock BJ, Sadock VA, editor Lippincott. Williams \& Wilkins: New York; 2000. p. 1298-1308.

3. Simon GE. Social and economic burden of mood disorders. Biol Psychiatry. 2003;54:208-215.

4. Bostwick JM, Pankratz VS. Affective disorders and suicide risk: a reexamination. Am J Psychiatry. 2000;157:1925-1932.

5. Soloff PH, Lynch KG, Kelly TM, Malone KM, Mann JJ. Characteristics of suicide attempts of patients with major depressive episode and borderline personality disorder: a comparative study. Am J Psychiatry. 2000;157:601-608.

6. World Health Organization Health Systems: Improving Performance. Geneva, Tertiary, 2000.

7. Mao Y, Hasselback P, Davies JW, Nichol R, Wigle DT. Suicide in Canada: an epidemiological assessment. Can J Public Health. 1990;81:324-328.

8. National Center for Health Statistics: Advance report of final mortality statistics. NCHS Monthly Vital Stat Rep. 1992:40.

9. Mann JJ. A current perspective of suicide and attempted suicide. Ann Intern Med. 2002;136:302-311.

10. Ahrens B, Linden M. Is there a suicidality syndrome independent of specific major psychiatric disorders? Result of a split half multiple regression analysis. Acta Psychiatr Scand. 1996;94:79-86.

11. Marttunen MJ, Aro HM, Henriksson MM, Lonnqvist JK. Mental disorders in adolescent suicide. DSM-III-R axes I and II diagnoses in suicides among 13- to 19-year-olds in Finland. Arch Gen Psychiatry. 1991;48:834-839.

12. Mann JJ. The neurobiology of suicide. Nat Med. 1998;4:25-30.

13. Blumenthal SJ, Kupfer DJ. Suicide over the life cycle: risk factors, assessment, and treatment of suicidal patients. Washington, DC. The American Psychiatric Press, Inc. 1999.

14. Turecki G. Dissecting the suicide phenotype: the role of impulsiveaggressive behaviors. J Psychiatry Neurosci. 2005;30:398-408.

15. Duman RS, Malberg J, Nakagawa S, D'Sa C. Neuronal plasticity and survival in mood disorders. Biol Psychiatry. 2000;48:732-739.
16. Duman RS. Pathophysiology of depression: the concept of synaptic plasticity. Eur Psychiatry. 2002;3:306-310.

17. Manji HK, Quiroz JA, Sporn J, et al. Enhancing neuronal plasticity and cellular resilience to develop novel, improved therapeutics for difficult-to-treat depression. Biol Psychiatry. 2003;53:707-742.

18. Fossati P, Radtchenko A, Boyer P. Neuroplasticity: from MRI to depressive symptoms. Eur Neuropsychopharmacol. 2004;5:S503-S510.

19. Altshuler LL, Casanova MF, Goldberg TE, Kleinman JE. The hippocampus and parahippocampus in schizophrenia, suicide, and control brains. Arch Gen Psychiatry. 1990;47:1029-1034.

20. Rajkowska G. Morphometric methods for studying the prefrontal cortex in suicide victims and psychiatric patients. Ann NY Acad Sci US A. 1997;836:253-268.

21. Ongur D, Drevets WC, Price JL. Glial reduction in the subgenual prefrontal cortex in mood disorders. Proc Natl Acad Sci USA. 1998;95:13290-13295.

22. Rosoklija G, Toomayan G, Ellis SP, et al. Structural abnormalities of subicular dendrites in subjects with schizophrenia and mood disorders: preliminary findings. Arch Gen Psychiatry. 2000;57:349-356.

23. Cotter D, Mackay D, Landau S, Kerwin R, Everall I. Reduced glial cell density and neuronal size in the anterior cingulate cortex in major depressive disorder. Arch Gen Psychiatry. 2001;58:545-553.

24. Rajkowska G. Hisopathology of the prefrontal cortex in depression: What does it tell us about dysfunctional monoaminergic circuits? Prog Brain Res. 2000;126:397-412.

25. Cotter D, Mackay D, Chana G, Beasley C, Landau S, Everall IP. Reduced neuronal size and glial cell density in area 9 of the dorsolateral prefrontal cortex in subjects with major depressive disorder. Cereb Cortex. 2002;12:386-394.

26. Miguel-Hidalgo J, Rajkowska G. Morphological brain changes in depression. Can antidepressants reverse them? CNS Drugs. 2002;16:361-372.

27. Rajkowska G. Cell pathology in mood disorders. Semin Clin Neuropsychiatry. 2002;7:281-292.

28. Aganova EA, Uranova NA. Morphometric analysis of synaptic contacts in the anterior limbic cortex in the endogenous psychoses. Neurosci Behav Physiol. 1992;22:59-65.

29. Drevets WC, Ongür D, Price JL. Reduced glucose metabolism in the subgenual prefrontal cortex in unipolar depression. Mol Psychiatry. 1998;3:190-191.

30. Dolan RJ, Bench CJ, Liddle PF, et al. Dorsolateral prefrontal cortex dysfunction in the major psychoses; symptom or disease specificity? J Neurol Neurosurg Psychiatry. 1993;56:1290-1294.

31. Andreasen NC. Linking mind and brain in the study of mental illnesses: a project for a scientific psychopathology. Science. 1997;275:1586-1593.

32. Honer WG. Assessing the machinery of mind: synapses in neuropsychiatric disorders. J Psychiatry Neurosci. 1999;24:116-121.

33. Toni N, Buchs PA, Nikonenko I, Bron CR, Muller D. LTP promotes formation of multiple spine synapses between a single axon terminal and a dendrite. Nature. 1999;402:421-425.

34. Hajsza T, MacLusky NJ, Leranth C. Short-term treatment with the antidepressant fluoxetine triggers pyramidal dendritic spine synapse formation in rat hippocampus. Eur J Neurosci. 2005;21:1299-12303.

35. McEwen BS. Effects of adverse experiences for brain structure and function. Biol Psychiatry. 2000;48:713-714.

36. Sheline YI. 3D MRI studies of neuroanatomic changes in unipolar depression: the role of stress and medical comorbidity. Biol Psychiatry. 2000;48:791-800.

37. Sala M, Perez J, Soloff P, et al. Stress and hippocampal abnormalities in psychiatric disorders. Eur Neuropsychopharmacol. 2004; 14:393-405.

38. Frodl T, Schaub A, Banac S, et al. Reduced hippocampal volume correlates with executive dysfunctioning in depression. J Psychiatry Neurosci. 2006;31:316-323.

39. Rajkowska G, Miguel-Hidalgo JJ. Gliogenesis and glial pathology in depression. CNS Neurol Disord Drug Targets. 2007;6:219-233. 
40. Sackeim HA. Functional brain circuits in depression and remission. Arch Gen Psychiatry. 2001;58:649-650.

41. Horan WP, Pogge DL, Borgaro SR, Stokes JM, Harvey PD. Learning and memory in adolescent psychiatric inpatients with depression: a normative study of the California Verbal Learning Test. Arch Clin Neuropsychol. 1997;12:575-584.

42. Porter RJ, Gallagher P, Thompson JM, Young AH. Neurocognitive impairment in drug-free patients with major depressive disorder. Br J Psychiatry. 2003;182:214-220.

43. Bearden CE, Glahn DC, Monkul ES, et al. Patterns of memory impairment in bipolar disorder and unipolar depression. Psychiatry Res. 2006;142:139-150.

44. Lewin GR, Barde YA. Physiology of the neurotrophins. Annu Rev Neurosci. 1996;19:289-317.

45. McAllister AK. Neurotrophins and neuronal differentiation in the central nervous system. Cell Mol Life Sci. 2001;58:1054-1060.

46. Sofroniew MV, Galletly NP, Isacson O, Svendsen CN. Survival of adult basal cholinergic neurons after loss of target neurons. Science. 1990;247:338-342.

47. Cooper JD, Skepper JN, Berzaghi MD, Lindholm D, Sofroniew MV. Delayed death of septal cholinergic neurons after excitotoxic ablation of hippocampal neurons during early postnatal development in the rat. Exp Neurol. 1996;139:143-155.

48. McAllister AK, Katz LC, Lo DC. Neurotrophins and synaptic plasticity. Annu Rev Neurosci. 1999;22:295-318.

49. Thoenen H. Neurotrophins and activity-dependent plasticity. Prog Brain Res. 2000;128:183-191.

50. Chao MV, Rajagopal R, Lee FS. Neurotrophin signaling in health and disease. Clin Sci (Lond). 2006;110:167-173.

51. Reichardt LF. Neurotrophin-regulated signalling pathways. Philos Trans R Soc Lond B Biol Sci. 2006;361:1545-1564.

52. Barbacid M. Neurotrophic factors and their receptors. Curr Opin Cell Biol. 1995; 7:148-155.

53. Schweigreiter R. The dual nature of neurotrophins. Bioessays. 2006;28:583-594.

54. Seidah NG, Benjannet S, Pareek S, Chrétien M, Murphy RA. Cellular processing of the neurotrophin precursors of NT3 and BDNF by the mammalian proprotein convertases. FEBS Lett. 1996;379:247-250.

55. Lu B, Pang PT, Woo NH. The yin and yang of neurotrophin action. Nat Rev Neurosci. 2005;6:603-614.

56. Egan MF, Kojima M, Callicott JH, et al. The BDNF val66met polymorphism affects activity-dependent secretion of BDNF and human memory and hippocampal function. Cell. 2003;112:144-145.

57. Mowla SJ, Pareek S, Farhadi HF, et al. Differential sorting of nerve growth factor and brain-derived neurotrophic factor in hippocampal neurons. J Neurosci. 1999;19:2069-2080.

58. Mowla SJ, Farhadi HF, Pareek S, et al. Biosynthesis and posttranslational processing of the precursor to brain-derived neurotrophic factor. J Biol Chem. 2001;276:12660-12666.

59. Chen ZY, Ieraci A, Teng H, et al. Sortilin controls intracellular sorting of brain-derived neurotrophic factor to the regulated secretory pathway. J Neurosci. 2005;25:6156-6166.

60. Lee R, Kermani P, Teng KK, Hempstead BL. Regulation of cell survival by secreted proneurotrophins. Science. 2001;294:1945-1948.

61. Pang PT, Teng HK, Zaitsev E, et al. Cleavage of proBDNF by tPA/plasmin is essential for long-term hippocampal plasticity. Science. 2004;306:487-491.

62. Mellstrom B, Torres B, Link WA, Naranjo JR. The BDNF gene: exemplifying complexity in $\mathrm{Ca} 2+-$ dependent gene expression. Crit Rev Neurobiol. 2004;16:43-49.

63. Pykel ES. Life stress, depression and attempted suicide. J Human Stress. 1976;2:3-12.

64. Luscomb RL, Clum GA, Patsiokas AT. Mediating factors in the relationship between life stress and suicide attempting. J Nerv Ment Disord. 1980;168:644-650.

65. Arato M, Banki CM, Bissette G, Nemeroff CB. Elevated CSF CRF in suicide victims. Biol Psychiatry. 1989;25:355-359.
66. Dooley D, Catalano R, Rook K, Serxner S. Economic stress and suicide: multilevel analyses. Part 1: Aggregate time-series analyses of economic stress and suicide. Suicide Life Threat Behav. 1989a;19:321-336.

67. Dooley D, Catalano R, Rook K, Serxner S. Economic stress and suicide: multilevel analyses. Part 2: Crosslevel analyses of economic stress and suicidal ideation. Suicide Life Threat Behav. 1989b;19:337-351.

68. Landau SF, Rehav G. Suicide and attempted suicide: their relation to subjective social stress indicators. Genet Soc Gen Psychol Monogr. 1989;115:273-274.

69. Josepho SA, Plutchik R. Stress, coping, and suicide risk in psychiatric inpatients. Suicide Life Threat Behav. 1994;24:48-57.

70. Westrin A. Stress system alterations and mood disorders in suicidal patients. Biomed Pharmacother. 2000;54:142-145.

71. France RD, Urban B, Krishnan KR, et al. CSF corticotrophin releasing factor-like immunoactivity in chronic pain patients with and without depression. Biol Psychiatry. 1988;23:86-88.

72. Nemeroff CB, Owens MJ, Bissette G, Andorn AC, Stanley M. Reduced corticotropin releasing factor binding sites in the frontal cortex of suicide victims. Arch Gen Psychiatry. 1988;45:577-579.

73. Lopez JF, Palkovits M, Arato M, Mansour A, Akil H, Watson SJ. Localization and quantification of proopiomelanocortin mRNA and glucocorticoid receptor mRNA in pituitaries of suicide victims. Neuroendocrinology. 1992;56:491-501.

74. Szigethy E, Conwell Y, Forbes NT, Cox C, Caine ED. Adrenal weight and morphology in victims of completed suicide. Biol Psychiatry. 1994;36:374-380.

75. Dumser T, Barocka A, Schubert E. Weight of adrenal glands may be increased in persons who commit suicide. Am J Forensic Med Pathol. 1998;19:72-76.

76. Lopez JF, Chalmers DT, Little KY, Watson SJ. Regulation of serotoninlA, glucocorticoid, and mineralocorticoid receptor in rat and human hippocampus: implications for the neurobiology of depression. Biol Psychiatry. 1998;43:547-573.

77. Lester D. The dexamethasone suppression test as an indicator of suicide: a meta-analysis. Pharmacopsychiatry. 1992;25:265-270.

78. Coryell W, Schlesser M. The dexamethasone suppression test and suicide prediction. Am J Psychiatry. 2001;158:748-753.

79. Coryell W, Young E, Carroll B. Hyperactivity of the hypothalamicpituitary-adrenal axis and mortality in major depressive disorder. Psychiatry Res. 2006;142:99-104.

80. Jokinen J, Carlborg A, Mårtensson B, Forslund K, Nordström AL, Nordström P. DST non-suppression predicts suicide after attempted suicide. Psychiatry Res. 2007;150:297-303.

81. Jokinen J, Nordström AL, Nordström P. CSF 5-HIAA and DST nonsuppression - orthogonal biologic risk factors for suicide in male mood disorder inpatients. Psychiatry Res. 2009a;165:96-102.

82. Jokinen J, Nordström P. HPA axis hyperactivity and attempted suicide in young adult mood disorder inpatients. J Affect Disord. 2009b; 116:117-120.

83. Smith MA, Makino S, Kvetnansky R, Post RM. Stress and glucocorticoids affect the expression of brain-derived neurotrophic factor and neurotrophin-3 mRNAs in the hippocampus. $J$ Neurosci. 1995;15:1768-1777.

84. Ueyama T, Kawai Y, Nemoto K, Sekimoto M, Toné S, Senba E. Immobilization stress reduced the expression of neurotrophins and their receptors in the rat brain. Neurosci Res. 1997;28:103-110.

85. Vaidya VA, Marek GJ, Aghajanian GK, Duman RS. 5-HT2A receptor-mediated regulation of brain-derived neurotrophic factor mRNA in the hippocampus and the neocortex. J Neurosci. 1997; 17:2785-2795.

86. Rasmusson AM, Shi L, Duman R. Downregulation of BDNF mRNA in the hippocampal dentate gyrus after re-exposure to cues previously associated with footshock. Neuropsychopharmacology. 2002;27:133-142.

87. Pizarro JM, Lumley LA, Medina W, et al. Acute social defeat reduces neurotrophin expression in brain cortical and subcortical areas in mice. Brain Res. 2004;1025:10-20. 
88. Roceri M, Hendriks W, Racagni G, Ellenbroek BA, Riva MA. Early maternal deprivation reduces the expression of BDNF and NMDA receptor subunits in rat hippocampus. Mol Psychiatry. 2002;7:609-616.

89. Chao HM, Sakai RR, Ma LY, McEwen BS. Adrenal steroid regulation of neurotrophic factor expression in the rat hippocampus. Endocrinology. 1998;139:3112-3118.

90. Schaaf MJM, Hoetelmans RWM, de Kloet ER, Vreugdenhil E. Corticosterone regulates expression of BDNF and trkB but not NT-3 and trkC mRNA in the rat hippocampus. $J$ Neurosci Res. 1997;48:334-341.

91. Schaaf MJM, de Jong J, de Kloet ER, Vreugdenhil E. Downregulation of BDNF mRNA and protein in the rat hippocampus by corticosterone. Brain Res. 1998;813:112-120.

92. Dwivedi Y, Rizavi HS, Pandey GN. Antidepressants reverse corticosterone-mediated decrease in BDNF expression: Dissociation in regulation of specific exons by antidepressants and corticosterone. Neuroscience. 2006a;139:1017-1029.

93. Barbany G, Persson H. Regulation of Neurotrophin mRNA Expression in the Rat Brain by Glucocorticoids. Eur J Neurosci. 1992;4:396-403.

94. Timmusk T, Palm K. Metsis M, et al. Multiple promoters direct tissue-specific expression of the rat BDNF gene. Neuron. 1993;10:475-489.

95. Nakayama M, Gahara Y, Kitamura T, Ohara O. Distinctive four promoters collectively direct expression of brain-derived neurotrophic factor gene. Mol Brain Res. 1994;21:206-218.

96. Marmigere F, Givalois L, Rage F, Arancibia S, Tapia-Arancibia L. Rapid induction of BDNF expression in the hippocampus during immobilization stress challenge in adult rats. Hippocampus. 2003;13:646-655.

97. Rage F, Givalois L, Marmigere F, Tapia-Arancibia L, Arancibia S. Immobilization stress rapidly modulates BDNF mRNA expression in the hypothalamus of adult male rats. Neurosci. 2002;112:309-318.

98. Nibuya M, Morinobu S, Duman RS. Regulation of BDNF and trkB mRNA in rat brain by chronic electroconvulsive seizure and antidepressant drug treatments. J Neurosci. 1995;15:7539-7547.

99. Nibuya M, Nestler EJ, Duman RS. Chronic antidepressant administration increases the expression of cAMP response element binding protein (CREB) in rat hippocampus. J Neurosci. 1996;16:2365-2372.

100. Russo-Neustadt A, Beard RC, Cotman CW. Exercise, antidepressant medications, and enhanced brain derived neurotrophic factor expression. Neuropsychopharmacology. 1999;21:679-682.

101. Coppell AL, Pei Q, Zetterström TS. Bi-phasic change in BDNF gene expression following antidepressant drug treatment. Neuropharmacology. 2003;44:903-910.

102. Dias BG, Banerjee SB, Duman RS, Vaidya VA. Differential regulation of brain-derived neurotrophin factor transcripts by antidepressant treatments in the adult rat brain. Neuropharmacology. 2003;45:553-563.

103. Van Hoomissen JD, Chambliss HO, Holmes PV, Dishman RK. Effects of chronic exercise and imipramine on mRNA for BDNF after olfactory bulbectomy in rat. Brain Res. 2003;974:228-235.

104. Xu H, Steven Richardson J, Li XM. Dose-related effects of chronic antidepressants on neuroprotective proteins BDNF, Bcl-2 and $\mathrm{Cu} / \mathrm{Zn}-\mathrm{SOD}$ in rat hippocampus. Neuropsychopharmacology. 2003;28:53-62.

105. Garza AA, Ha TG, Garcia C, Chen MJ, Russo-Neustadt AA. Exercise, antidepressant treatment, and BDNF mRNA expression in the aging brain. Pharmacol Biochem Behav. 2004;77:209-220.

106. De Foubert G, Carney SL, Robinson CS, et al. Fluoxetine-induced change in rat brain expression of brain-derived neurotrophic factor varies depending on length of treatment. Neuroscience. 2004;128:597-604.

107. Vinet J, Carra S, Blom JM, Brunello N, Barden N, Tascedda F. Chronic treatment with desipramine and fluoxetine modulate BDNF, CaMKKalpha and CaMKKbeta mRNA levels in the hippocampus of transgenic mice expressing antisense RNA against the glucocorticoid receptor. Neuropharmacology. 2004;47:1062-1069.
108. Rogóz Z, Skuza G, Legutko B. Repeated treatment with mirtazepine induces brain-derived neurotrophic factor gene expression in rats. J Physiol Pharmacol. 2005;56:661-671.

109. Neeper SA, Gómez-Pinilla F, Choi J, Cotman CW. Physical activity increases mRNA for brain-derived neurotrophic factor and nerve growth factor in rat brain. Brain Res. 1996;726:49-56.

110. Müller MB, Toschi N, Kresse AE, Post A, Keck ME. Long-term repetitive transcranial magnetic stimulation increases the expression of brain-derived neurotrophic factor and cholecystokinin mRNA, but not neuropeptide tyrosine mRNA in specific areas of rat brain. Neuropsychopharmacology. 2000;23:205-215.

111. Marvanová M, Lakso M, Pirhonen J, Nawa H, Wong G, Castrén E. The neuroprotective agent memantine induces brain-derived neurotrophic factor and trkB receptor expression in rat brain. Mol Cell Neurosci. 2001;18:247-258.

112. Newton SS, Collier EF, Hunsberger J, et al. Gene profile of electroconvulsive seizures: induction of neurotrophic and angiogenic factors. J Neurosci. 2003;23:10841-10851.

113. Altar CA, Laeng P, Jurata LW, et al. Electroconvulsive seizures regulate gene expression of distinct neurotrophic signaling pathways. J Neurosci. 2004;24:2667-2677.

114. Lauterborn JC, Truong GS, Baudry M, Bi X, Lynch G, Gall CM. Chronic elevation of brain-derived neurotrophic factor by ampakines. J Pharmacol Exp Ther. 2003;307:297-305.

115. Russo-Neustadt AA, Alejandre H, Garcia C, Ivy AS, Chen MJ. Hippocampal brain-derived neurotrophic factor expression following treatment with reboxetine, citalopram, and physical exercise. Neuropsychopharmacology. 2004;29:2189-2199.

116. Alfonso J, Frick LR, Silberman DM, Palumbo ML, Genaro AM, Frasch AC. Regulation of hippocampal gene expression is conserved in two species subjected to different stressors and antidepressant treatments. Biol Psychiatry. 2006;59:244-251.

117. Fujimaki K, Morinobu S, Duman RS. Administration of a cAMP phosphodiesterase 4 inhibitor enhances antidepressant-induction of BDNF mRNA in rat hippocampus. Neuropsychopharmacology. 2000;22:42-51.

118. Altieri M, Marini F, Arban R, Vitulli G, Jansson BO. Expression analysis of brain-derived neurotrophic factor (BDNF) mRNA isoforms after chronic and acute antidepressant treatment. Brain Res. 2004;1000:148-155.

119. Zetterström TS, Pei Q, Madhav TR, Coppell AL, Lewis L, Grahame-Smith DG. Manipulations of brain 5-HT levels affect gene expression for BDNF in rat brain. Neuropharmacology. 1999;38:1063-1073.

120. Miró X, Pérez-Torres S, Artigas F, Puigdomènech P, Palacios JM, Mengod G. Regulation of cAMP phosphodiesterase mRNAs expression in rat brain by acute and chronic fluoxetine treatment. An in situ hybridization study. Neuropharmacology. 2002;43:1148-1157.

121. Saarelainen T, Hendolin P, Lucas G, et al. Activation of the TrkB neurotrophin receptor is induced by antidepressant drugs and is required for antidepressant-induced behavioral effects. J Neurosci. 2003;23:349-357.

122. Monteggia LM, Barrot M, Powell CM, et al. Essential role of brainderived neurotrophic factor in adult hippocampal function. Proc Natl Acad Sci U S A. 2004;101:10827-10832.

123. Barbacid M. The Trk family of neurotrophin receptors. J Neurobiol. 1994;25:1386-1403.

124. Dechant G, Rodriguez-Tebar A, Brade YA. Neurotrophin receptors. Prog Neurobiol. 1994;42:347-372.

125. Middlemas DS, Lindberg RA, Hunter T. TrkB, a neural receptor protein-tyrosine kinase: evidence for a full-length and two truncated receptors. Mol Cell Biol. 1991;11:143-153.

126. Schlessinger J, Ullrich A. Growth factor signaling by receptor tyrosine kinases. Neuron. 1992;9:383-391.

127. Watson FL, Heerssen HM, Moheban DB, et al. Rapid nuclear responses to target-derived neurotrophins require retrograde transport of ligand-receptor complex. J Neurosci. 1999;19:7889-7900. 
128. Allendoerfer KL, Cabelli RJ, Escandon E, Kaplan DR, Nikolics K, Shatz CJ. Regulation of neurotropin receptors during the maturation of the mammalian visual system. J Neurosci. 1994;4:1795-1811.

129. Armanini MP, McMahon SB, Sutherland J, Shelton DL, Philips HS. Truncated and catalytic isoforms of TrkB are co-expressed in neurons of rat and mouse CNS. Eur J Neurosci. 1995; 7:1403-1409.

130. Eide EF, Vining ER, Eide BL, Zang K, Wang XY, Reichardt LF. Naturally occurring truncated TrkB receptors have dominant inhibitory effects on brain-derived neurotrophic factor signaling. J Neurosci. 1996;16:3123-3129.

131. Rantamäki T, Knuuttila JE, Hokkanen ME, Castrén E. The effects of acute and long-term lithium treatments on trkB neurotrophin receptor activation in the mouse hippocampus and anterior cingulate cortex. Neuropharmacology. 2006;50:421-427.

132. Rantamäki T, Hendolin P, Kankaanpää A, et al. Pharmacologically diverse antidepressants rapidly activate brain-derived neurotrophic factor receptor TrkB and induce phospholipase-C gamma signaling pathways in mouse brain. Neuropsychopharmacology. 2007;32:2152-2162.

133. Zörner B, Wolfer DP, Brandis D, et al. Forebrain-specific trkB-receptor knockout mice: behaviorally more hyperactive than "depressive". Biol Psychiatry. 2003;54:972-982.

134. Siuciak JA, Lewis DR, Wiegand SJ, Lindsay RM. Antidepressant-like effect of brain-derived neurotrophic factor (BDNF). Pharmacol Biochem Behav. 1997;J56:131-137.

135. Shirayama Y, Chen AC, Nakagawa S, Russell DS, Duman RS. Brain-derived neurotrophic factor produces antidepressant effects in behavioral models of depression. J Neurosci. 2002;22:3251-3261.

136. Altar CA. Neurotrophins and depression. Trends Pharmacol Sci. 1999;20:59-61.

137. Hoshaw BA, Malberg JE, Lucki I. Central administration of IGF-I and BDNF leads to long-lasting antidepressant-like effects. Brain Res. 2005;1037:204-208.

138. Chen B, Dowlatshahi D, MacQueen GM, Wang JF, Young LT. Increased hippocampal BDNF immunoreactivity in subjects treated with antidepressant medication. Biol Psychiatry. 2001;50:260-265.

139. Karege F, Schwald M, Cisse M. Postnatal developmental profile of brain-derived neurotrophic factor in rat brain and platelets. Neurosci Lett. 2002;328:261-264.

140. Karege F, Perret G, Bondolfi G, Schwald M, Bertschy G, Aubry JM. Decreased serum brain-derived neurotrophic factor levels in major depressed patients. Psychiatry Res. 2002;109:143-148.

141. Karege F, Bondolfi G, Gervasoni N, Schwald M, Aubry JM, Bertschy G. Low brain-derived neurotrophic factor (BDNF) levels in serum of depressed patients probably results from lowered platelet BDNF release unrelated to platelet reactivity. Biol Psychiatry. 2005a;57:1068-1072.

142. Gonul AS, Akdeniz F, Taneli F, Donat O, Eker C, Vahip S. Effect of treatment on serum brain-derived neurotrophic factor levels in depressed patients. Eur Arch Psychiatry Clin Neurosci. 2005;255:381-386.

143. Piccinni A, Marazziti D, Catena M, et al. Plasma and serum brain-derived neurotrophic factor (BDNF) in depressed patients during 1 year of antidepressant treatments. J Affect Disord. 2008;105:279-283.

144. Matrisciano F, Bonaccorso S, Ricciardi A, et al. Changes in BDNF serum levels in patients with depression disorder (MDD) after 6 months treatment with sertraline, escitalopram, or venlafaxine. J Psychiatr Res. 2009; 43:247-254

145. Aydemir O, Deveci A, Taneli F. The effect of chronic antidepressant treatment on serum brain-derived neurotrophic factor levels in depressed patients: a preliminary study. Prog Neuropsychopharmacol Biol Psychiatry. 2005;29:261-265.

146. Yoshimura R, Mitoma M, Sugita A, et al. Effects of paroxetine or milnacipran on serum brain-derived neurotrophic factor in depressed patients. Prog Neuropsychopharmacol Biol Psychiatry. 2007;3:1034-1037.
147. Hellweg R, Ziegenhorn A, Heuser I, Deuschle M. Serum concentrations of nerve growth factor and brain-derived neurotrophic factor in depressed patients before and after antidepressant treatment. Pharmacopsychiatry. 2008;41:66-71.

148. Lang UE, Bajbouj M, Gallinat J, Hellweg R. Brain-derived neurotrophic factor serum concentrations in depressive patients during vagus nerve stimulation and repetitive transcranial magnetic stimulation. Psychopharmacology (Berl). 2006;187:156-159.

149. Bocchio-Chiavetto L, Zanardini R, Bortolomasi M, et al. Electroconvulsive Therapy (ECT) increases serum Brain Derived Neurotrophic Factor (BDNF) in drug resistant depressed patients. Eur Neuropsychopharmacol. 2006;16:620-624.

150. Brunoni AR, Lopes M, Fregni F. A systematic review and meta-analysis of clinical studies on depression and BDNF levels: implications for the role of neuroplasticity in depression. Int J Neuropsychopharmacol. 2008;11:1169-1180.

151. Sen S, Duman R, Sanacora G. Serum brain-derived neurotrophic factor, depression, and antidepressant medications: meta-analyses and implications. Biol Psychiatry. 2008;64:527-532.

152. Chen ZY, Patel PD, Sant G, et al. Variant brain-derived neurotrophic factor (BDNF) (Met66) alters the intracellular trafficking and activitydependent secretion of wild-type BDNF in neurosecretory cells and cortical neurons. J Neurosci. 2004;24:4401-4411.

153. Sheline YI, Wang PW, Gado MH, Csernansky JG, Vannier MW. Hippocampal atrophy in recurrent depression. Proc Natl Acad $\mathrm{Sci}$ US A. 1996;93:3908-3913.

154. Sheline YI, Gado MH, Kraemer HC. Untreated depression and hippocampal volume loss. Am J Psychiatry. 2003;160:1516-1518.

155. Frodl T, Schüle C, Schmitt G, et al. Association of the brainderived neurotrophic factor Val66Met polymorphism with reduced hippocampal volumes in depression. Arch Gen Psychiatry. 2007;64: 410-416.

156. Pezawas L, Verchinski BA, Mattay VS, et al. The brain-derived neurotrophic factor val66met polymorphism and variation in human cortical morphology. J Neurosci. 2004;24:10099-10102.

157. Szeszko PR, Lipsky R, Mentschel C, et al. Brain-derived neurotrophic factor val66met polymorphism and volume of the hippocampal formation. Mol Psychiatry. 2005;10:631-636.

158. Bueller JA, Aftab M, Sen S, Gomez-Hassan D, Burmeister M, Zubieta JK. BDNF Val66Met allele is associated with reduced hippocampal volume in healthy subjects. Biol Psychiatry. 2006;59:812-815.

159. Hariri AR, Goldberg TE, Mattay VS, et al. Brain-derived neurotrophic factor val66met polymorphism affects human memory-related hippocampal activity and predicts memory performance. J Neurosci. 2003;23:6690-6694.

160. Kleim JA, Chan S, Pringle E, et al. BDNF val66met polymorphism is associated with modified experience-dependent plasticity in human motor cortex. Nat Neurosci. 2006;9:735-737.

161. Cheeran B, Talelli P, Mori F, et al. A common polymorphism in the brain-derived neurotrophic factor gene (BDNF) modulates human cortical plasticity and the response to rTMS. J Physiol. 2008;586:5717-5725.

162. Tsai SJ, Cheng CY, Yu YW, Chen TJ, Hong CJ. Association study of a brain-derived neurotrophic-factor genetic polymorphism and major depressive disorders, symptomatology, and antidepressant response. Am J Med Genet B Neuropsychiatr Genet. 2003;123B:19-22.

163. Choi MJ, Kang RH, Lim SW, Oh KS, Lee MS. Brain-derived neurotrophic factor gene polymorphism (Val66Met) and citalopram response in major depressive disorder. Brain Res. 2006;1118:176-182.

164. Licinio J, Dong C, Wong ML. Novel sequence variations in the brainderived neurotrophic factor gene and association with major depression and antidepressant treatment response. Arch Gen Psychiatry. 2009;66:488-497.

165. Hwang JP, Tsai SJ, Hong CJ, Yang CH, Lirng JF, Yang YM. The Val66Met polymorphism of the brain-derived neurotrophic-factor gene is associated with geriatric depression. Neurobiol Aging. 2006;27:1834-1837. 
166. Duncan LE, Hutchison KE, Carey G, Craighead WE. Variation in brain-derived neurotrophic factor (BDNF) gene is associated with symptoms of depression. J Affect Disord. 2009;115:215-219.

167. Savitz J, van der Merwe L, Stein DJ, Solms M, Ramesar R. Genotype and childhood sexual trauma moderate neurocognitive performance: a possible role for brain-derived neurotrophic factor and apolipoprotein E variants. Biol Psychiatry. 2007;64(39):1-9.

168. Grassi-Oliveira R, Stein LM, Lopes RP, Teixeira AL, Bauer ME. Low plasma brain-derived neurotrophic factor and childhood physical neglect are associated with verbal memory impairment in major depression - a preliminary report. Biol Psychiatry. 2008;64: 281-285.

169. Gatt JM, Nemeroff CB, Dobson-Stone C, et al. Interactions between BDNF Val66Met polymorphism and early life stress predict brain and arousal pathways to syndromal depression and anxiety. Mol Psychiatry. 2009;14:681-695.

170. Aguilera M, Arias B, Wichers M, et al. Early adversity and 5-HTT/BDNF genes: new evidence of gene-environment interactions on depressive symptoms in a general population. Psychol Med. In press 2009.

171. Lang UE, Hellweg R, Kalus P, et al. Association of a functional BDNF polymorphism and anxiety-related personality traits. Psychopharmacology (Berl). 2005;180:95-99.

172. Hünnerkopf R, Strobel A, Gutknecht L, Brocke B, Lesch KP. Interaction between BDNF Val66Met and dopamine transporter gene variation influences anxiety-related traits. Neuropsychopharmacology. 2007;32:2552-2560.

173. Joffe RT, Gatt JM, Kemp AH, et al. Brain derived neurotrophic factor Val66Met polymorphism, the five factor model of personality and hippocampal volume: Implications for depressive illness. Hum Brain Mapp. 2009;30:1246-1256.

174. Terracciano A, Sanna S, Uda M, et al. Genome-wide association scan for five major dimensions of personality. Mol Psychiatry. [Epub ahead of print]. 2008

175. Savitz J, Solms M, Ramesar R. The molecular genetics of cognition: dopamine, COMT and BDNF. Genes Brain Behav. 2006;5:311-328.

176. Mill J, Petronis A. Molecular studies of major depressive disorder: the epigenetic perspective. Mol Psychiatry. 2007;12:799-814.

177. Chen WG, Chang Q, Lin Y, et al. Derepression of BDNF transcription involves calcium-dependent phosphorylation of MeCP2. Science. 2003;302:885-889.

178. Martinowich K, Hattori D, Wu H, et al. DNA methylation-related chromatin remodeling in activity-dependent BDNF gene regulation. Science. 2003;302:890-893.

179. Fuchikami M, Morinobu S, Kurata A, Yamamoto S, Yamawaki S. Single immobilization stress differentially alters the expression profile of transcripts of the brain-derived neurotrophic factor (BDNF) gene and histone acetylation at its promoters in the rat hippocampus. Int $J$ Neuropsychopharmacol. 2009;12:73-82.

180. Tsankova NM, Berton O, Renthal W, Kumar A, Neve RL, Nestler EJ. Sustained hippocampal chromatin regulation in a mouse model of depression and antidepressant action. Nat Neurosci. 2006;9:519-525.

181. Dwivedi Y, Rizavi HS, Conley RR, Roberts RC, Tamminga CA, Pandey GN. Altered gene expression of brain-derived neurotrophic factor and receptor tyrosine kinase B in postmortem brain of suicide subjects. Arch Gen Psychiatry. 2003:60.

182. Karege F, Vaudan G, Schwald M, Perroud N, La Harpe R. Neurotrophin levels in postmortem brains of suicide victims and the effects of antemortem diagnosis and psychotropic drugs. Brain Res Mol Brain Res. 2005b;136:29-37

183. Kozicz T, Tilburg-Ouwens D, Faludi G, Palkovits M, Roubos E. Gender-related urocortin 1 and brain-derived neurotrophic factor expression in the adult human midbrain of suicide victims with depression. Neuroscience. 2008;152:1015-1023.

184. Pandey GN, Ren X, Rizavi HS, Conley RR, Roberts RC, Dwivedi Y. Brain-derived neurotrophic factor and tyrosine kinase $\mathrm{B}$ receptor signalling in post-mortem brain of teenage suicide victims. Int $J$ Neuropsychopharmacol. 2008;11:1047-1061.
185. Deveci A, Aydemir O, Taskin O, Taneli F, Esen-Danaci A. Serum BDNF levels in suicide attempters related to psychosocial stressors: a comparative study with depression. Neuropsychobiology. 2007;56:93-97.

186. Kim YK, Lee HP, Won SD, et al. Low plasma BDNF is associated with suicidal behavior in depression. Prog Neuropsychopharmacol Biol Psychiatry. 2007;31:578-579.

187. Lee BH, Kim H, Park SH, Kim YK. Decreased plasma BDNF level in depressive patients. J Affect Disord. 2007;101:239-244.

188. Lee BH, Kim YK. Reduced platelet BDNF level in patients with depression. Prog Neuropsychopharmacol Biol Psychiatry. 2009 Apr 14. [Epub ahead of print].

189. Dawood T, Anderson J, Barton D, et al. Reduced overflow of BDNF from the brain is linked with suicide risk in depressive illness. Mol Psychiatry. 2007;12:981-983.

190. Hong CJ, Huo SJ, Yen FC, Tung CL, Pan GM, Tsai SJ. Association study of a brain-derived neurotrophic-factor genetic polymorphism and mood disorders, age of onset and suicidal behavior. Neuropsychobiology. 2003;48:186-189.

191. Kim B, Kim CY, Hong JP, Kim SY, Lee C, Joo YH. Brain-derived neurotrophic factor $\mathrm{Val} / \mathrm{Met}$ polymorphism and bipolar disorder. Association of the Met allele with suicidal behavior of bipolar patients. Neuropsychobiology. 2008;5(82):97-103.

192. Sarchiapone M, Carli V, Roy A, et al. Association of polymorphism (Val66Met) of brain-derived neurotrophic factor with suicide attempts in depressed patients. Neuropsychobiology. 2008;57:139-145.

193. Zarrilli F, Angiolillo A, Castaldo G, et al. Brain derived neurotrophic factor (BDNF) genetic polymorphism (Val66Met) in suicide: A study of 512 cases. Am J Med Genet B Neuropsychiatr Genet. 2008 Aug 29. [Epub ahead of print].

194. Perroud N, Courtet P, Vincze I, et al. Interaction between BDNF Val66Met and childhood trauma on adult's violent suicide attempt. Genes Brain Behav. 2008;7:314-322.

195. Fryer RH, Kaplan DR, Feinstein SC, Radeke MJ, Grayson DR, Kromer LF. Developmental and mature expression of full-length and truncated TrkB receptors in the rat forebrain. J Comp Neurol. 1996;374:21-40.

196. Dwivedi Y, Rizavi H, Zhang H, et al. Neurotrophin receptor activation and expression in human postmortem brain: effect of suicide. Biol Psychiatry. 2009;65:319-328.

197. Ernst C, Deleva V, Deng X, et al. Alternative splicing, methylation state, and expression profile of tropomyosin-related kinase B in the frontal cortex of suicide completers. Arch Gen Psychiatry. 2009; 66:22-32.

198. Frade JM, Barde YA. Nerve growth factor: two receptors, multiple functions. BioEssays. 1998;20:137-145.

199. Hasegawa Y, Yamagishi S, Fujitani M, Yamashita T. p75 neurotrophin receptor signaling in the nervous system. Biotechnol Annu Rev. 2004;10:123-149.

200. Hempstead BL, Martin-Zanca D, Kaplan DR, Parada LF, Chao MV. High-affinity NGF binding requires co-expression of the trk proto-oncogene and the low-affinity NGF receptor. Nature. 1991;350:678-683.

201. Benedetti M, Levi A, Chao MV. Differential expression of nerve growth factor receptors leads to altered binding affinity and neurotrophin responsiveness. Proc Natl Acad Sci USA. 1993;90:7859-7863.

202. Esposito D, Patel P, Stephens RM, et al. The cytoplasmic and transmembrane domains of the $\mathrm{p} 75$ and Trk A receptors regulate high affinity binding to nerve growth factor. J Biol Chem. 2001;276:32687-32695.

203. Meldolesi J, Sciorati C, Clementi E. The p75 receptor: first insights into the transduction mechanisms leading to either cell death or survival. Trends Pharmacol Sci. 2000;21:242-243.

204. Rabizadeh S, Oh J, Zhong L, Yang J, Bitler CM, Butcher LL. Induction of apoptosis by the low-affinity NGF receptor. Science. 1993;261:345-358. 
205. Casaccia-Bonnefil P, Carter BD, Dobrowsky RT, Chao MV. Death of oligodendrocytes mediated by the interaction of nerve growth factor with its receptor p75. Nature. 1996;383:716-719.

206. Friedman WJ, Grossman J. Neurotrophins induce death of cultured hippocampal neurons. Soc Neurosci Abstr. 1999;25:767.

207. Friedman W. Neurotrophins induce death of hippocampal neurons via the p75 receptor. $J$ Neurosci. 2000;28:6340-6346.

208. Roux PP, Colicos MA, Barker PA, Kennedy TE. p75 neurotrophin receptor expression is induced in apoptotic neurons after seizure. J Neurosci. 1999;19:6887-6896.

209. Miller FD, Kaplan DR. Neurotrophin signaling pathways regulating neuronal apoptosis. Cell Mol Life Sci. 2001;58:1045-1053.

210. Dwivedi Y, Mondal AC, Rizavi HS, Conley RR. Suicide brain is associated with decreased expression of neurotrophins. Biol Psychiatry. 2005;58:315-324.

211. Mukai J, Hachiya T, Shoji-Hoshino S, et al. NADE, a p75NTRassociated cell death executor, is involved in signal transduction mediated by the common neurotrophin receptor p75NTR. $J$ Biol Chem. 2000;275:17566-17570.

212. Salehi AH, Roux PP, Kubu CJ, et al. NRAGE, a novel MAGE protein, interacts with the p75 neurotrophin receptor and facilitates nerve growth factor-dependent apoptosis. Neuron. 2000;27:279-288.

213. Jordan BW, Dinev D, LeMellay V, et al. Neurotrophin receptorinteracting mage homologue is an inducible inhibitor of apoptosis protein-interacting protein that augments cell death. $J$ Biol Chem. 2001;276:39985-39989.

214. Whitfield J, Neame SJ, Paquet L, Bernard O, Ham J. Dominantnegative c-Jun promotes neuronal survival by reducing BIM expression and inhibiting mitochondrial cytochrome c release. Neuron. 2001;29:629-643.

215. Yoon SO, Cassaccia-Bonnefil P, Carter B, Chao MV. Competitive signaling between TrkA and $\mathrm{p} 75$ nerve growth factor receptors determines cell survival. $J$ Neurosci. 1998;18:3273-3281.

216. Mazzoni IE, Said FA, Aloyz R, Miller FD, Kaplan D. Ras regulates sympathetic neuron survival by suppressing the p53-mediated cell death pathway. J Neurosci. 1999;19:9716-9727.

217. Dobrowsky RT, Jenkins GM, Hannun YA. Neurotrophins induce sphingomyelin hydrolysis-modulation by co-expression of p75NTR with trk receptors. J Biol Chem. 1995;270:22135-22142.

218. Bilderback TR, Gazula VR, Dobrowsky RT. Phosphoinositide 3-kinase crosstalk between Trk A tyrosine kinase and p75NTR dependent sphingolipid signaling pathways. Neurochem. 2001;76:1540-1551.

219. Müller G, Storz P, Bourteele S, Döppler H, Pfizenmaier K, Mischak H. Regulation of Raf-1 kinase by TNF via its second messenger ceramide and cross-talk with mitogenic signalling. EMBO J. $1998 ; 17: 732-742$

220. Zhou H, Summers SA, Birnbaum MJ, Pittman RN. Inhibition of Akt kinase by cell-permeable ceramide and its implications for ceramide-induced apoptosis. J Biol Chem. 1998;273:16568-16575.
221. Zundel W, Schindler C, Haas-Kogan D, Koong A, Kaper F, Chen E. Loss of PTEN facilitates HIF-1-mediated gene expression. Genes Dev. 2000;14:391-396.

222. Dwivedi Y, Rizavi HS, Roberts RC, Conley RC, Tamminga CA, Pandey GN. Reduced activation and expression of ERK1/2 MAP kinase in the postmortem brain of depressed suicide subjects. J Neurochem. 2001;77:916-928.

223. Dwivedi Y, Rizavi HS, Conley RR, Pandey GN. ERK MAP kinase signaling in post-mortem brain of suicide subjects: differential regulation of upstream Raf kinases Raf-1 and B-Raf. Mol Psychiatry. 2006b;11:86-98.

224. Dwivedi Y, Rizavi HS, Teppen T, et al. Lower phosphoinositide 3-kinase (PI 3-kinase) activity and differential expression levels of selective catalytic and regulatory PI 3-kinase subunit isoforms in prefrontal cortex and hippocampus of suicide subjects. Neuropsychopharmacology. [Epub ahead of print] PMID: 18075493. 2008.

225. Hempstead BL. The many faces of p75NTR. Curr Opin Neurobiol. 2002;12:260-267.

226. Woo NH, Teng HK, Siao CJ, et al. Activation of p75NTR by proBDNF facilitates hippocampal long-term depression. Nat Neurosci. 2005;8:1069-1077.

227. Figurov A, Pozzo-Miller LD, Olafsson P, Wang T, Lu B. Regulation of synaptic responses to high-frequency stimulation and LTP by neurotrophins in the hippocampus. Nature. 1996;381:706-709.

228. McGregor S, Strauss J, Bulgin N, et al. p75(NTR) gene and suicide attempts in young adults with a history of childhood-onset mood disorder. Am J Med Genet B Neuropsychiatr Genet. 2007;144B: 696-700.

229. MacQueen GM, Ramakrishnan K, Croll SD, et al. Performance of heterozygous brain-derived neurotrophic factor knockout mice on behavioral analogues of anxiety, nociception, and depression. Behav Neurosci. 2001;115:1145-1153.

230. Koponen E, Voikar V, Riekki R, et al. Transgenic mice overexpressing the full-length neurotrophin receptor trkB exhibit increased activation of trkB/PLC-? pathway, reduced anxiety, and facilitated learning. Mol Cell Neurosci. 2004;26:166-181.

231. Koponen E, Rantamäki T, Voikar V, Saarelainen T, MacDonald E, Castrén E. Enhanced BDNF signaling is associated with an antidepressant-like behavioral response and changes in brain monoamines. Cell Mol Neurobiol. 2005;6:973-980.

232. Takei N, Inamura N, Kawamura M, et al. Brain-derived neurotrophic factor induces mammalian target of rapamycin-dependent local activation of translation machinery and protein synthesis in neuronal dendrites. J Neurosci. 2004;24:9760-9769.

233. Schratt GM, Tuebing F, Nigh EA, et al. A brain-specific microRNA regulates dendritic spine development. Nature. 2006;439:283-289.
Neuropsychiatric Disease and Treatment

\section{Publish your work in this journal}

Neuropsychiatric Disease and Treatment is an international, peerreviewed journal of clinical therapeutics and pharmacology focusing on concise rapid reporting of clinical or pre-clinical studies on a range of neuropsychiatric and neurological disorders. This journal is indexed on PubMed Central, the 'PsycINFO' database and CAS, and is the official

\section{Dovepress}

journal of The International Neuropsychiatric Association (INA). The manuscript management system is completely online and includes a very quick and fair peer-review system, which is all easy to use. Visit http://www.dovepress.com/testimonials.php to read real quotes from published authors. 